\title{
Energy, Exergy, Environmental Impact and Economic (4E) Analysis of ET-CPC-Powered Solar Domestic Water Heating System
}

Dinesh K Sharma ( $\nabla$ dinesh.sharma@skit.ac.in )

Swami Keshvanand Institute of Technology Management and Gramothan https://orcid.org/00000003-3919-1900

\section{Dilip Sharma}

Malaviya National Institute of Technology Department of Mechanical Engineering Ahmed Hamza H. Ali

Assiut University Faculty of Engineering

\section{Research Article}

Keywords: Energy, Exergy, Environmental impact, Economic, evacuated tube, compound parabolic concentrator

Posted Date: January 17th, 2022

DOI: https://doi.org/10.21203/rs.3.rs-1150649/v1

License: (a) This work is licensed under a Creative Commons Attribution 4.0 International License. Read Full License 
Energy, Exergy, Environmental Impact and Economic (4E) Analysis of ET-CPCpowered Solar Domestic Water Heating System

\title{
Author1 (Corresponding Author)
}

\section{Dinesh Kumar Sharma}

${ }^{1}$ Department of Mechanical Engineering,

Swami Keshavanand Institute of Technology, Management and Gramothan, Jaipur302017, India

${ }^{2}$ Department of Mechanical Engineering, Malaviya National Institute of Technology, Jaipur-302017, India

\section{Email: dinesh.sharma@skit.ac.in}

\section{Author 2}

\section{Dilip Sharma}

${ }^{2}$ Department of Mechanical Engineering, Malaviya National Institute of Technology, Jaipur-302017, India

Email: sharmadmnit@gmail.com

\section{$\underline{\text { Author } 3}$}

\author{
Ahmed Hamza H. Ali ${ }^{3}$ \\ ${ }^{3}$ Department of Mechanical Engineering, Assiut University, Assiut-71516, Egypt \\ Email: drahmedhamza@yahoo.com,ah-hamza@aun.edu.eg
}


3 Dinesh Kumar Sharma ${ }^{1,2 *}$, Dilip Sharma², Ahmed Hamza H. Ali ${ }^{3}$

$4 \quad{ }^{1}$ Department of Mechanical Engineering, Swami Keshavanand Institute of Technology, Management and

5 Gramothan, Jaipur-302017, India

$6{ }^{2}$ Department of Mechanical Engineering, Malaviya National Institute of Technology, Jaipur-302017,

7 India

$8{ }^{3}$ Department of Mechanical Engineering, Faculty of Engineering, Assiut University, Assiut-71516, Egypt

*Corresponding Author: dinesh.sharma@skit.ac.in

\section{Abstract}

11 World energy demand is increasing continuously; consequently, the environmental impact forces

12 towards utilizing renewable energy resources with efficient and optimized cost-performance

13 conversion technologies. Therefore in this study, an analytical model is developed to propose the

14 energy, exergy, environmental impact and economic (4E) analysis of the water heating system at

15 Jaipur (India) with evacuated tube compound parabolic concentrator ET-CPC field of the total

16 area of $81 \mathrm{~m}^{2}$. The model results were validated with the experimental data, and a good

17 agreement has prevailed. After that, the model is used to perform parametric studies on the effect

18 of operating and meteorological parameters on the productivity and performance of the system.

19 Moreover, the system's performance, environmental impact and economic aspects have been

20 investigated and compared under different meteorological conditions at four different locations

21 in Rajasthan (India) using TMY2 weather data files. Results clarified that Jodhpur receives the

22 highest solar radiation intensity from these four locations. Consequently, the results indicate the

23 highest annual energy and exergy with the value of 79.72 MWh and 9.311 MWh followed by

24 Jaisalmer, Barmer, and Jaipur. The economic analysis results clarified that the simple payback 
period ranged from 4.5 to 4.75 years and the discounted payback period ranged from 6.6 to 7

26 years based on a $6 \%$ discount rate. At the same time, the Levelized Cost of Heating (LCOH)

27 ranges from 1.62 to $1.72 \mathrm{INR} / \mathrm{kWh}$ of heat compared to closest with $\mathrm{CNG}$ as fuel ranging from

284.39 to $4.41 \mathrm{INR} / \mathrm{kWh}$ for specified locations. The internal rate of return is reported to be 16.76 ,

$2916.82,16.77$, and $16.75 \%$ for Barmer, Jodhpur, Jaipur, and Jaisalmer respectively, and savings of

$3074400,78125,75371$, and $73813 \mathrm{~kg}$ of $\mathrm{CO}_{2}$ emission to the environment.

\section{Keywords}

32 Energy; Exergy; Environmental impact; Economic; evacuated tube; compound parabolic concentrator.

\section{Nomenclature}

$\begin{array}{lll}34 & \text { CC } & \text { construction cost } \\ 35 & \text { CF } & \text { cash inflows } \\ 36 & \text { CPC } & \text { compound parabolic concentrator } \\ 37 & \text { DPBP } & \text { discounted payback period } \\ 38 & \text { ETC } & \text { evacuated tube collector } \\ 39 & \text { ET-CPC } & \text { evacuated tube with compound parabolic concentrator } \\ 40 & \text { FPC } & \text { flat plate collector } \\ 41 & \text { IRR } & \text { internal rate of return } \\ 42 & \text { LCOH } & \text { Levelized Cost of Heating } \\ 43 & \text { PCM } & \text { phase change material } \\ 44 & \text { PTC } & \text { parabolic trough collector } \\ 45 & \text { RTD } & \text { resistance temperature detector } \\ 46 & \text { SDWH } & \text { solar domestic water heating } \\ 47 & \text { SPBP } & \text { simple payback period } \\ 48 & \text { SPV } & \text { solar photo-voltaic } \\ 49 & \text { STC } & \text { solar thermal collector } \\ 50 & \text { TES } & \text { thermal energy storage } \\ 51 & \text { TLCC } & \text { total life cycle cost } \\ 52 & & \\ 53 & \text { Symbols and } & \text { notations } \\ 54 & \text { A } & \left.\text { area (m }{ }^{2}\right) \\ 55 & \mathrm{C}_{\mathrm{f}} & \text { specific heat }(\mathrm{J} / \mathrm{kg} . \mathrm{K}) \\ 56 & \mathrm{D} & \text { tube diameter }(\mathrm{m}) \\ 57 & \mathrm{dt} & \text { time difference }(\mathrm{s}) \\ 58 & \text { Ex } & \left.\text { exergy (W/m }{ }^{2}\right) \\ 59 & \mathrm{f} & \text { friction factor } \\ 60 & \mathrm{~F}_{\mathrm{R}} & \text { heat removal factor } \\ 61 & \mathrm{I}_{\mathrm{T}} & \text { total solar radiation }(\mathrm{W} / \mathrm{m} 2) \\ 62 & \mathrm{~L} & \text { length (m) } \\ 63 & \dot{\mathrm{m}}_{\mathrm{f}} & \text { mass flow rate }(\mathrm{kg} / \mathrm{s}) \\ & & \end{array}$




$\begin{array}{lll}64 & \mathrm{P} & \text { pressure }(\mathrm{kPa}) \\ 65 & \mathrm{Q}_{\text {useful }} & \text { useful heat gain }(\mathrm{kWh}) \\ 66 & \mathrm{~V} & \text { fluid velocity }(\mathrm{m} / \mathrm{s}) \\ 67 & \mathrm{U}_{\mathrm{L}} & \text { overall heat coefficient }\left(\mathrm{W} / \mathrm{m}^{2} . \mathrm{K}\right)\end{array}$

68

69

$70 \alpha$

$71 \rho$

$72 \eta$

$73 \mu$

$74 \tau$

$\begin{array}{ll}75 & \text { Subscript } \\ 76 & \text { amb } \\ 77 & \text { c } \\ 78 & \text { f } \\ 79 & \text { in } \\ 80 & \text { m } \\ 81 & \text { n } \\ 82 & \text { out } \\ 83 & \text { r }\end{array}$

\author{
absorptivity \\ density \\ efficiency \\ kinematic viscosity \\ transmissivity
}

\section{1. Introduction}

85 Once a luxury afforded to a precious few, energy has become a commodity that the modern world cannot

86 survive without (Shekarchian et al. 2013). Most of the day-to-day needs of modern society are rigorously

87 increasing the energy demand whether it refers to cooling, heating, or power. Presently, conventional

88 sources dominate to produce electricity and are responsible for contributing harmful pollutants to the

89 environment. Renewable energy such as solar energy has been proven to meet the energy demand

90 partially or fully without carbon footprints being a clean fuel. Solar thermal collectors (STCs) and solar

91 photo-voltaic panels (SPVs) are widely accepted for harnessing solar energy and further utilizing it for

92 cooling, heating, and power. Flat plate collectors (FPCs), compound parabolic concentrator (CPC),

93 evacuated tube collectors (ETCs), parabolic trough collectors (PTCs), etc. are some of the popular STC

94 technologies. Recent innovations and technology advancements such as evacuated tube integrated with

95 CPC (termed as ET-CPC), evacuated tube integrated with PTC, and many others are with improved

96 productivity and efficiency by lowering losses to the environment which resulted in achieving higher 
working temperature. Out of these, ET-CPCs are the most preferred for medium operational temperature range (up to $150^{\circ} \mathrm{C}$ ) applications being a stationary type of STC. At the same time, these offer better productivity utilizing diffusive and direct radiations with efficiency ranging from 35 to $55 \%$.

100 101 102 103 104 105

Domestic/community water heating is an essential application that is relatively energy-intensive, and the use of conventional resources such as kerosene, natural gas, wood, coal, and electricity is quite expensive and emits harmful emissions. Formerly, FPCs have been primarily promoted but as time progressed, technology advancement in STCs took place as discussed above. Sokhansefat et al. (2018) compared the FPC and ETC solar collectors in cold climatic conditions based on thermoeconomic and environmental impact analysis. It was reported that the performance of the ETC system is $41 \%$ better than the FPC system, and the yearly practical heat gain of ETC is $30 \%$ more than that of FPC in any climate zone. Hazami et al. (2013) reported a year-round energy performance monitoring results of a new type of domestic solar water heating system (DSWH) based on ETC. It was also reported that ETC generated about 9\% more energy than the FPC under the same climatic condition. Kabeel et al. (2020) reported improved thermal performance of modified ETC with the help of hybrid storage materials and low-cost concentrators. Thermal efficiency improvement of modified design for using hybrid storage materials reached $72.1 \%$. They used $0.0,2,3,4$, and $5 \%$ graphite nanomaterial mass concentration as hybrid storage materials.

Geete et al. (2019) fabricated compound parabolic solar collectors with evacuated tubes and analyzed the thermal performance of the system. Instantaneous energy efficiency was reported to be $69.87 \%$ during their experimental work. Jiang et al. (2015) concluded from their studies that CPC integrated ETCs (ETCPCs) showed $50 \%$ efficiency at $200^{\circ} \mathrm{C}$ using mineral oils. Ma et al. (2010) reported that improving thermal conductance of working fluid from 5 to $40 \mathrm{~W} / \mathrm{m}$.K using ET-CPCs helped increase the efficiency by $10 \%$ and outlet temperature by $16 \%$. Hence, the use of CPC reflectors at the backside of the ETC tubes is helpful to increase the collector efficiency by improving the overall aperture area. Similarly, Pie et al. (2012) analyzed the evacuated tube CPC and concluded that the concentrator is helpful to improve the 
122 thermal performance of the ETC in high-temperature ranges. Further, Mills et al. (1986) reported a study 123 on the effect of the acceptance angle of CPC on the performance of the evacuated tubes. They concluded 124 that the acceptance angle is less decisive but the aperture area. Performance of ET-CPC is reported to 125 have negligible effect from the selection of orientations from either North-South or East-West. The 126 selection of reflector material was also discussed and suggested that the use of polished stainless steel is 127 better in terms of cost-effectiveness, durability, and maintenance compared to other mirror materials.

128 Previously, Mishra et al. (2017) compared the performance of ETC and ET-CPC based on energy and 129 exergy analyses. It was reported that $27.28 \%$ extra gain was observed in energy by using evacuated tube CPC compared to that of without CPC. Kerme et al. (2017) presented energy and exergy analysis of solar131 powered vapor absorption systems. Furthermore, the result also indicated that the main source of the 132 exergy destruction is the solar collector. In the solar collector, $71.9 \%$ of the input exergy was destroyed 133 which accounted for $84 \%$ of the total exergy loss. Chopra et al. (2021) reported a 4E analysis of a PCM 134 (palmatic acid) embedded ETC-powered solar water heating system. A significant improvement was 135 shown in energy, exergy, and $\mathrm{CO}_{2}$ mitigation with the use of ETC with PCM compared to without PCM. 136 The results claimed a rise of $36-44 \%$ in energy efficiency whereas a rise of $28-35 \%$ was observed in 137 exergy efficiency with the use PCM filled in annular space between absorber and tube of ETC.

138 Battisti and Corrado (2005) applied environmental analysis and optimization to the water storage coupled 139 solar thermal collector. Simapro software program was used to obtain environmental indicators. It was 140 found that the reduction of the impacts could be up to $40 \%$ and the environmental payback times were 514119 months. Faizal et al. (2015) applied the energy, exergy, economic, and environmental analysis on a 142 flat-plate solar collector operated with $\mathrm{SiO}_{2}$ nanofluid. It was found that the energy and exergy 143 efficiencies of nanofluids were higher than base fluids. Also, $\mathrm{CO}_{2}$ emissions and payback periods of 144 nanofluids are better. Bellos et al. (2017) reported a 4E analysis for a solar-assisted refrigeration system 145 for various operating scenarios. Evacuated tube collectors fed heat to the generator of the vapour 
147 years.

148 Thus, it can be concluded that ET-CPCs are quite efficient at elevated temperatures up to $200^{\circ} \mathrm{C}$ and have 149 no need for a solar tracking mechanism, which makes them a preferred choice over FPC. Along with this, 150 these utilize diffuse and direct types of solar radiation. The thermodynamic performance of ET-CPCs based solar water heating systems has been measured through energy and exergy analyses. Energy analysis is conservative as per the first law of thermodynamics which typically involves energy efficiency and gain. On the other hand, exergy analysis helps to determine the energy transactions based on quality.

154 Exergy analysis denotes the maximum theoretical work that can be obtained in a given set of environmental conditions. Hence, a thermodynamic system can be better assessed with the help of an exergy method (Caliskan 2017). Also, exergy analysis helps to determine the sustainability of the system

157 (Moran and Shapiro 1993). An overall analysis of the system is incomplete without understanding its monetary transactions and environmental impact during its entire useful life (Dincer and Rosen 2007a)(Meyer et al. 2009)(Tsatsaronis and Morosuk 2012). The first law of thermodynamics is widely used for energy utilization analysis. However, it is limited because it is incapable of quantitatively 161 determining the quality of energy. On the other hand, the second law of thermodynamics supplants this 162 limitation by introducing the exergy analysis that quantifies the potential helpful work for a given amount 163 of energy. Therefore, it is essential that both the quantity and quality of the energy used for practical 164 energy usage be considered (Saidur et al. 2013)(Cengel and Boles 2019). Expressing the true efficiency 165 makes the exergy a powerful tool in sectoral energy analysis and engineering design (Rosen and Dincer 166 1997). It should be pointed out that economic analysis is indirectly affected by environmental impact and 167 energy analysis results.

168 In the present work, an analytical model is developed to carry out energy, exergy, environmental impact 169 and economic analysis of an $81 \mathrm{~m}^{2}$ ET-CPC powered solar water heating system equipped with thermal 170 energy storage. Along with this, a parametric study is also performed to report the effect of mass flow 
171 rate, solar radiation intensity, and ambient temperature on productivity and efficiency of reported 172 installation at various fluid inlet temperatures. It was identified that overall analysis of ET-CPC-based 173 applications are less reported in the literature and thus sufficient data is not available which can be 174 otherwise helpful to promote its use. Thus, the thermodynamic performance of the SDWH system with its 175 environmental impact and economic aspects has been investigated and compared under meteorological 176 conditions of four different locations of Rajasthan (India) using TMY2 weather data files.

\section{2. System Description and Methodology}

178 The system presented in this research is installed at the roof and front lawn of the Department of 179 Mechanical Engineering, Malaviya National Institute of Technology, Jaipur $\left(26.86^{\circ} \mathrm{N}, 75.81^{\circ} \mathrm{E}\right)$. The 180 schematic and actual photograph is presented in Figure 1. Each ET-CPC module has an effective area of 3 $\mathrm{m}^{2}$. As shown in Figure 1, the installed ET-CPC field is arranged as six rows having four ET-CPCs in series, and one row has three ET-CPCs in-series constituting a total aperture area of $81 \mathrm{~m}^{2}$ with 27 ETCPC modules. These ET-CPCs are connected with a sensible thermal energy storage tank (containing soft water as a working medium) with the help of a centrifugal pump. Figure 2 shows the pictorial view of the ET-CPC solar field. The technical descriptions of the ET-CPC, thermal energy storage tank, and pump are provided in Table 1. There is no load considered to this system in the specified time. Various thermocouples, RTDs, and flow meters have been installed as shown in Figure 1 and a 16 channel Masibus $85 x x+$ data logger has been used to integrate these data.

This study developed an analytical model for energy, exergy, environmental impact and economic analysis of this SDWH. Further, experimental validation of the model is carried out using energetic efficiency and useful heat gain from the system. A parametric study is also made to investigate the effect of the mass flow rate of working fluid, solar radiation intensity, and ambient temperature on the productivity and efficiency of the system. Four potential locations have been identified from Rajasthan

194 (India); Barmer, Jodhpur, Jaisalmer, and Jaipur. Weather data have been taken from the TMY2 file of 
197 the specified locations. As discussed earlier, no analysis could be decisive without environmental and 198 economic evaluation. Hence, environmental analysis is carried out to show the amount of $\mathrm{CO}_{2}$ emissions 199 saved. In the latter section, economic analysis is done while comparing SDWH with the conventional 200 methods of water heating.

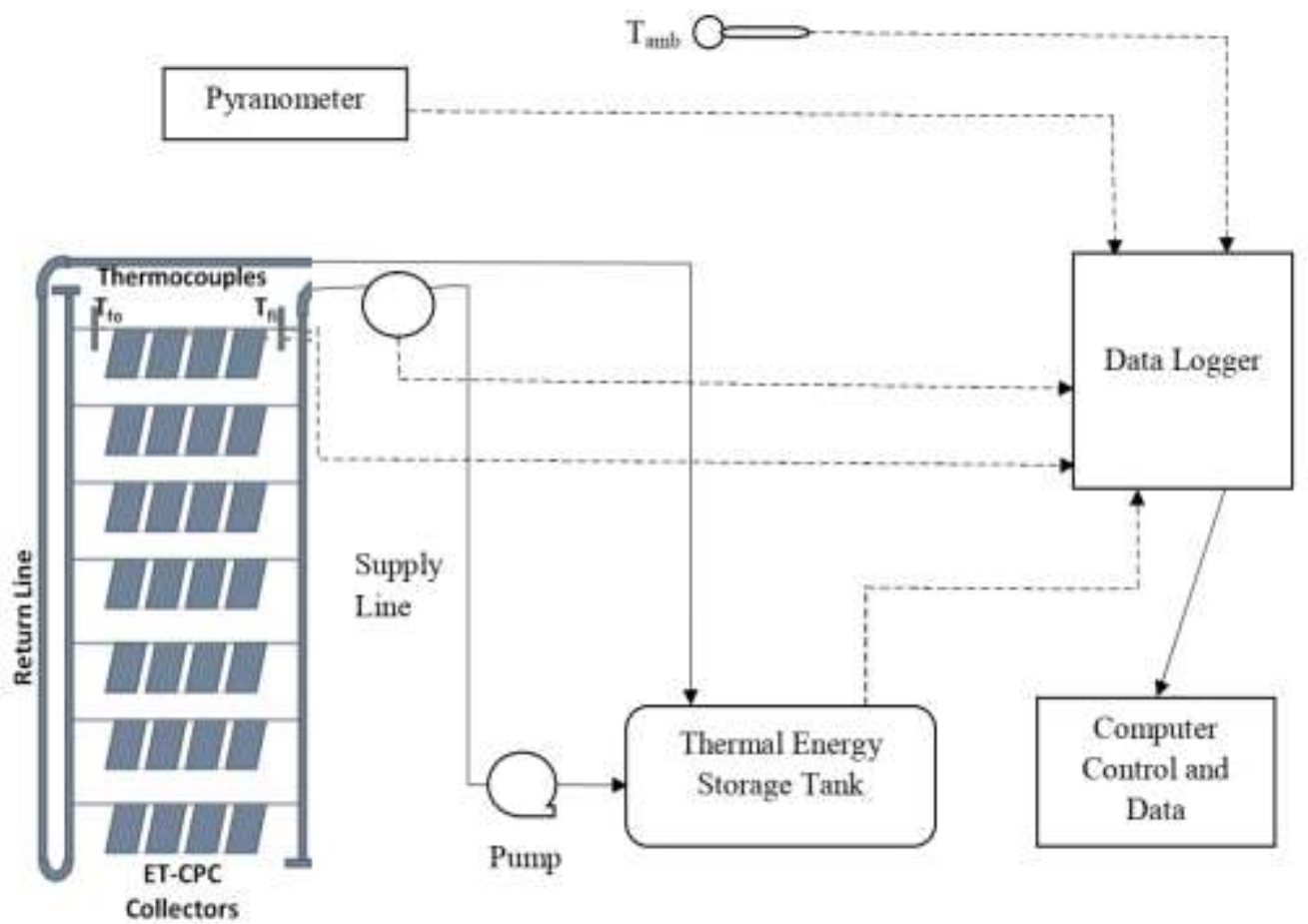

Figure 1 Schematic diagram of ET-CPC solar domestic water heating system

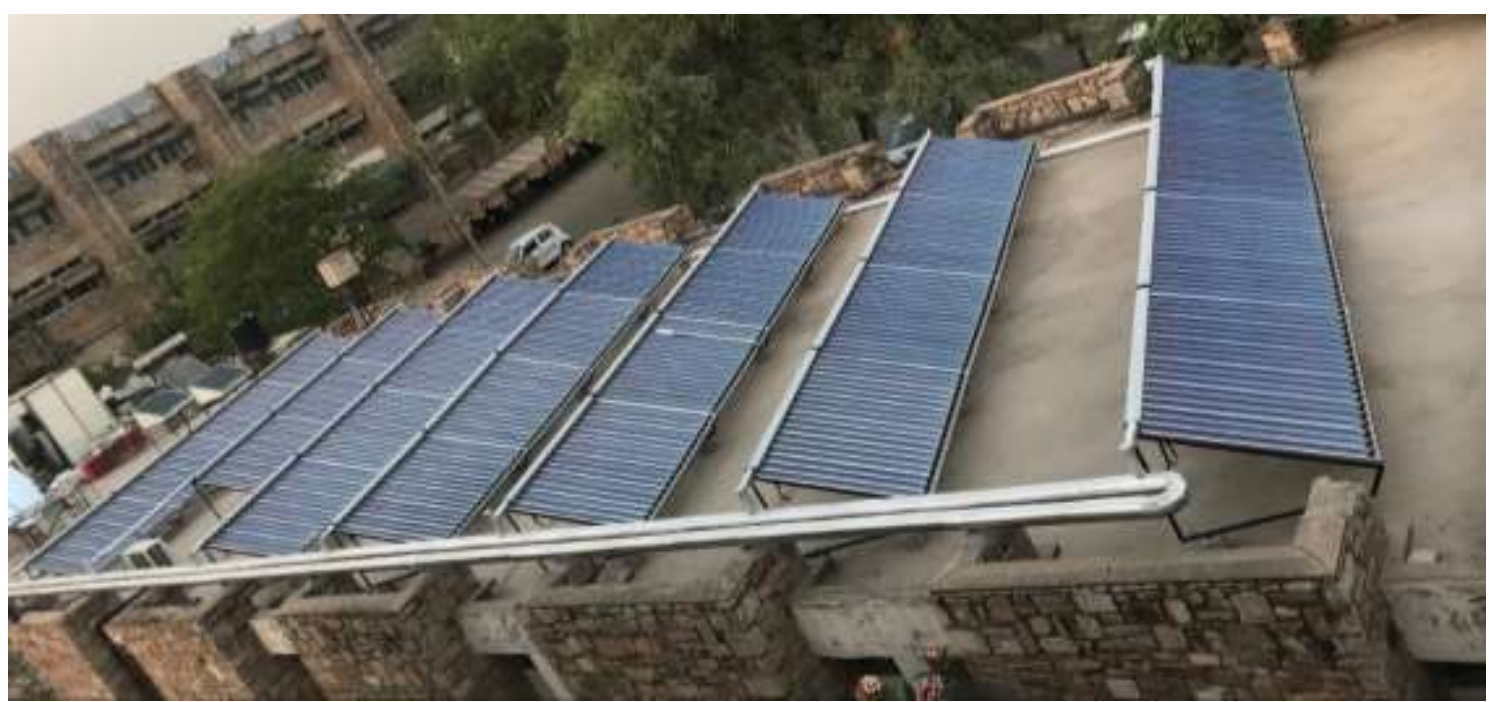


Figure 2 Pictorial view of ET-CPC solar collector field installed on MNIT, Jaipur roof top

Table 1 Technical description of the various components in the system

\begin{tabular}{|c|c|c|}
\hline Description & Unit & Technical Specification \\
\hline \multicolumn{3}{|l|}{ Solar Collectors } \\
\hline No. of evacuated tubes & nos. & 18 \\
\hline$\prod_{0}$ concerning aperture,EN12975 & $\%$ & 64.2 \\
\hline Heat transfer Coefficient $\left(a_{1}\right)$ & $\left(\mathrm{W} / \mathrm{m}^{2} \mathrm{~K}\right)$ & 0.89 \\
\hline Temperature dependent transfer & $\left(\mathrm{W} / \mathrm{m}^{2} \mathrm{~K}^{2}\right)$ & 0.001 \\
\hline \multicolumn{3}{|l|}{ Coefficient $\left(\mathrm{a}_{2}\right)$} \\
\hline Grid dimensions & $\mathrm{m}$ & $2.08 \times 1.64 \times 0.10$ \\
\hline Aperture area & $\mathrm{m}^{2}$ & 3.41 \\
\hline Max Working overpressure & bar & 10 \\
\hline Max Stagnation temperature & ${ }^{\circ} \mathrm{C}$ & 250 \\
\hline Glass Tube Material & & Borosilicate Glass 3.3 \\
\hline Selective Absorber coating material & & Aluminum Nitride \\
\hline $\begin{array}{l}\text { Glass Tube ( } \begin{array}{c}\Phi \text { Ext/ } \\
\text { Thickness/Tube length) }\end{array} \\
\text { Int/ Wall }\end{array}$ & $\mathrm{mm}$ & $47 / 37 / 1.6 / 1500$ \\
\hline Make & & Linuo-Ritter \\
\hline \multicolumn{3}{|l|}{ Hot Storage Tank } \\
\hline Tank Diameter & $\mathrm{m}$ & 1 \\
\hline Tank Length & $\mathrm{m}$ & 3.5 \\
\hline Volume of Tank & $\mathrm{m}^{3}$ & 2.2 \\
\hline Material of Tank & & Mild Steel \\
\hline Insulation Material & & $\begin{array}{l}\text { Fiberglass of } 50 \mathrm{~mm} \text { thickness } \\
\text { cladded with aluminium sheet }\end{array}$ \\
\hline Orientation of Tank & & Horizontal \\
\hline \multicolumn{3}{|l|}{ Hot Water Pump } \\
\hline Hot Water Pump at $25 \mathrm{~m}$ head & $\mathrm{m}^{3} / \mathrm{hr}$ & 5.4 \\
\hline
\end{tabular}

Table 2 Design parameters of ET-CPC field

\begin{tabular}{ll}
\hline Parameter & Value \\
\hline $\mathbf{R}$ & $0.0185 \mathrm{~m}$ \\
$\mathbf{C}_{\mathbf{f}}$ & $4186 \mathrm{~J} / \mathrm{kg} . \mathrm{K}$ \\
$\mathbf{L}$ & $1500 \mathrm{~mm}$ \\
$\mathbf{A r}_{\mathbf{r}}$ & $0.1734 \mathrm{~m}^{2}$ \\
$\mathbf{A}$ & $0.2215 \mathrm{~m}^{2}$ \\
$\mathbf{A}_{\mathbf{c}, \text { total }}$ & $81 \mathrm{~m}^{2}$ \\
$\mathbf{n}$ & 12 \\
$\boldsymbol{\tau}$ & 0.95 \\
\hline
\end{tabular}




\begin{tabular}{ll}
\hline $\boldsymbol{\alpha}$ & 0.80 \\
$\boldsymbol{\rho f}_{\text {f }}$ & $997 \mathrm{~kg} / \mathrm{m}^{3}$ \\
$n \&_{f}$ & $0.0357(\mathrm{~kg} / \mathrm{s})$ \\
$\mathbf{U}_{\text {tpa }}$ & $2.1 \mathrm{~W} / \mathrm{m}^{2} . \mathrm{K}$ \\
$\mathbf{h}_{\mathbf{p f}}$ & $100 \mathrm{~W} / \mathrm{m}^{2} . \mathrm{K}$ \\
$\mathbf{F}$ & 0.986 \\
\hline
\end{tabular}

\section{Energy, Exergy, Environment impact and Economic Analysis}

\subsection{Energy analysis of ET-CPC}

210 Energy analysis for ET-CPC first involves the rise in fluid inlet temperature upon exit point from

211 the ET-CPC arrays. This temperature gain is achieved from the equations developed by Mishra

212 et al. (2017). It's essential to understand the flow distribution inside an ET-CPC module so that

213 assessment of flow rate inside a tube could be done perfectly. Figure 3 shows the flow scattering

214 inside a single module of ET-CPC which supports the precise number of evacuated tubes linked

215 in series in the current setup.

Table 3 Energy Analysis of ET-CPC

Energy Analysis of ET-CPC

Eq. No.

$\mathrm{T}_{\text {out, } \mathrm{n}}$ outlet temperature from the $\mathrm{n}^{\text {th }}$ ET-CPCs coupled in series is deliberate as in

(Mishra et al. 2015):

$T_{\text {out }, n}=\frac{\left(A_{c} F_{R} \alpha \tau\right)_{1}}{n k_{f} C_{f}} \times \frac{\left(1-K_{e f f}\right)^{n}}{\left(1-K_{\text {eff }}\right)} I_{T}+\frac{\left(A_{r} F_{R} U_{L}\right)_{1}}{n k_{f} C_{f}} \times \frac{\left(1-K_{e f f}\right)^{n}}{\left(1-K_{\text {eff }}\right)} T_{a m b}+K_{\text {eff }}^{n} T_{\text {in }}$

Where,

$$
\begin{aligned}
& K_{e f f}=1-\frac{A_{r} F_{R} U_{L:}}{\operatorname{r\& f}_{\mathrm{f}} C_{f}} \\
& F_{R}=\frac{n \&_{f} C_{f}}{U_{L} A_{r}}\left[1-\exp \left(-\frac{2 \pi r L U_{L}}{n \&_{f} C_{f}}\right)\right]
\end{aligned}
$$

Practical heat gain for the n-tube connected in series is given as:

$Q_{u s e f u l, n}=(\alpha \tau)_{e f f} I_{T}-(U A)_{e f f}\left(T_{i n}-T_{a m b}\right)$ 
Where,

$$
\begin{aligned}
& (\alpha \tau)_{e f f}=A_{c} F_{R} \alpha \tau\left(\frac{1-K_{e f f}^{n}}{1-K_{e f f}}\right) \\
& (U A)_{e f f}=A_{r} F_{R} U_{L}\left(\frac{1-K_{e f f}^{n}}{1-K_{e f f}}\right)
\end{aligned}
$$

Instantaneous thermal efficiency ( $\left.\eta_{\text {Instantaneous }}\right)$ is given as

$$
\eta_{\text {Instantanous }}=\frac{Q_{\text {useful }}}{\eta_{\text {opt }} \times A_{c, \text { total }} \times I_{T}}
$$

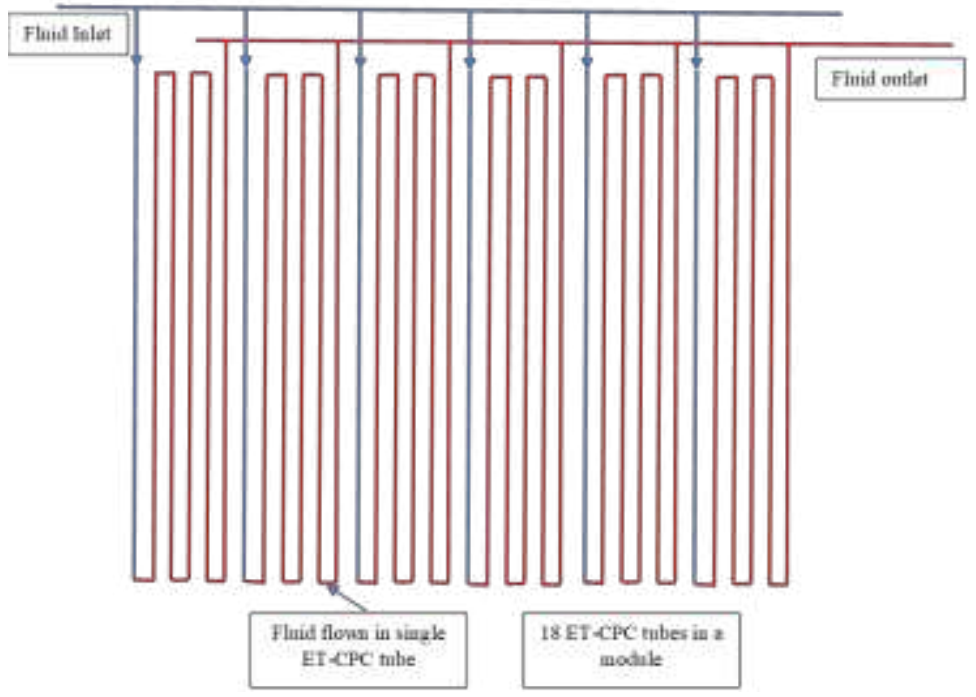

Figure 3 Fluid Flow Diagram inside an ET-CPC module

221 Table 3 describes reduced equations for desired energy analysis of ET-CPC solar field. In the 222 existing setup, each ET-CPC module involves 18 evacuated tubes and four modules linked in 223 series to create an array and equally 7 rows are arranged parallel. Hence, 12 tubes are linked in 224 series and hence mass flow rate is distributed in 7 rows and 6 subdivisions. Hence, a total mass 225 flow rate is $0.83 \mathrm{~kg} / \mathrm{s}$ out of centrifugal pump rated discharge $1.5 \mathrm{~kg} / \mathrm{s}$ because of pressure drop 
226 due to ET-CPC solar collectors but only $0.0198 \mathrm{~kg} / \mathrm{s}$ mass flow rate is observed inside any

227 particular evacuated tube for this setup as shown in Figure 3.

228 Since this system's thermal energy storage is $2.2 \mathrm{~m}^{3}$ in volume and oriented horizontally, a 229 complete energy mix model is considered inside the TES tank. Further, energy gain is calculated 230 as the successive sum of the energy gains, and subsequent temperature rise at any given time is

231 treated as per equation (3) of Table 3.

\section{$232 \quad 3.2 \quad$ Exergy analysis of ET-CPC}

233 As stated in the Introduction section, reported literature mainly considers the physical conditions

234 for exergy analysis and further for exergy gain. These models did not reflect the actual in-sight 235 on the exergy destructions in each phase. Thus presented model is prepared concerning various 236 possible destructions while performing exergy analysis therefore, accurate results could be 237 presented. Figure 4 reports the various exergy destructions from an ET-CPC tube, and table 4 238 shows the various equations reduced for exergy analysis.

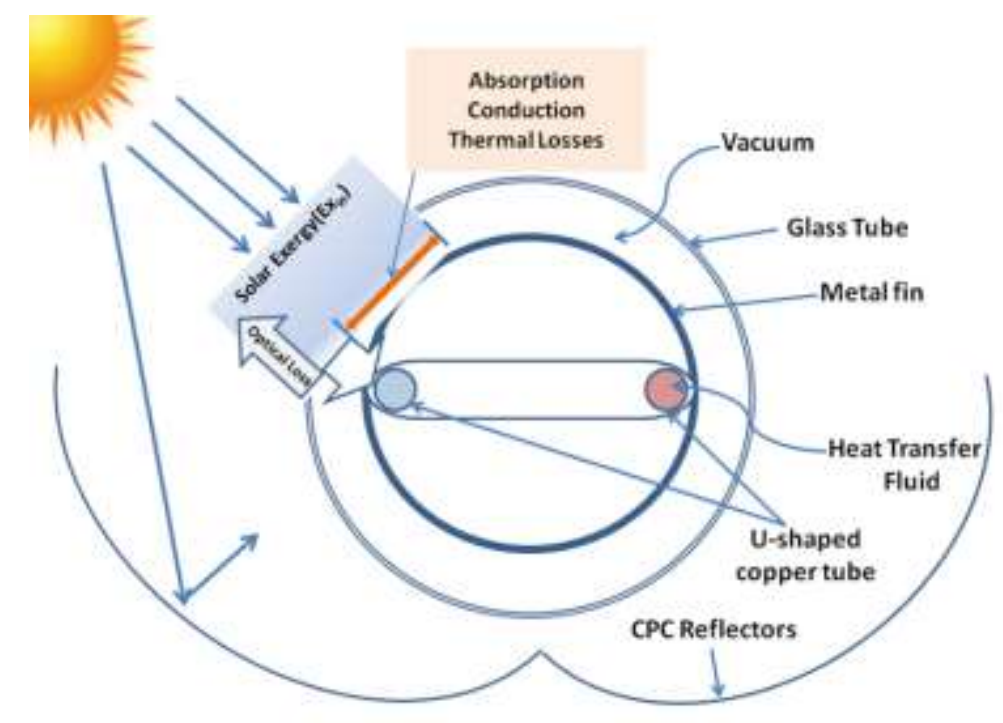


Exergy balance equation in the steady-state condition

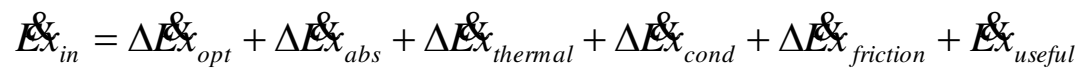

Exergy inlet (Petela 2003, 2005)

$$
\begin{aligned}
& E_{\text {Sun }}=E_{\text {in }}=A_{c, \text { total }} I_{T} \varphi_{\text {solar rad,max }} \\
& \varphi_{\text {Solarrad,max }}=\left[1+\frac{1}{3}\left(\frac{T_{\text {amb }}}{T_{\text {sun }}}\right)^{4}-\frac{4}{3}\left(\frac{T_{\text {amb }}}{T_{\text {sun }}}\right)\right]
\end{aligned}
$$

Exergy destruction due to optical

$$
\Delta x_{o p t}=E x_{\text {sun }}\left(1-\eta_{\text {opt }}\right)
$$

Exergy destruction due to absorption

$$
\Delta E_{\text {abs }}=\eta_{\text {opt }}\left(E_{\text {sun }}-I_{T} \times A_{c, \text { total }}\left(1-\frac{T_{\text {amb }}}{T_{\text {receiver }}}\right)\right)
$$

\section{Exergy destruction due to thermal losses}

$$
\Delta E_{\text {thermal }}=K_{\text {loss }}\left(T_{\text {sufface }}-T_{\text {amb }}\right)\left(1-\frac{T_{\text {amb }}}{T_{\text {surface }}}\right)
$$

\section{Exergy destruction due to conduction}

$$
\begin{aligned}
& \Delta \mathbb{E}_{\text {cond }}=T_{\text {amb }}\left(\Delta S_{\text {cond }}\right) \\
& \Delta S_{\text {cond }}=\int_{\text {Tin }}^{\text {Tout }} \frac{n \&_{f} C_{f} d T}{T}-\frac{1}{T_{\text {receiver }}} \int_{\text {Tin }}^{\text {Tout }} n k_{f} C_{f} d T \\
& \Delta S_{\text {cond }}=n k_{f} C_{f}\left[\ln \left(\frac{T_{\text {out }}}{T_{\text {in }}}\right)-\left(\frac{T_{\text {out }}-T_{\text {in }}}{T_{\text {receiver }}}\right)\right]
\end{aligned}
$$

Exergy destruction due to pipe friction (Bejan et al. 1981)

$$
\begin{aligned}
& \Delta E x_{\text {friction }}=\frac{n \&_{f} T_{a m b} \Delta P}{\rho_{f} T_{i n}} \\
& \Delta P=f \rho_{f} L \frac{V^{2}}{2 D}
\end{aligned}
$$




$$
\begin{aligned}
& f=\frac{64}{\operatorname{Re}}, \text { for } \operatorname{Re} \leq 2200 \\
& f=0.316 \operatorname{Re}^{-0.25}, \text { for } \operatorname{Re}>2200 \\
& \operatorname{Re}=\frac{\rho_{f} V D}{\mu_{f}}
\end{aligned}
$$

\section{Exergy useful}

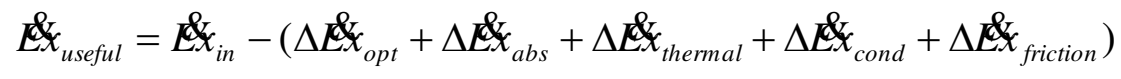

Total Exergy gain

$$
E x_{\text {gain,total }}=\int E x_{\text {useful }} \cdot A_{\text {total }} \cdot d t
$$

\section{Exergetic efficiency}

$$
\psi_{\text {exergetic }}=\frac{E E_{\text {useful }}}{E x_{\text {in }}}
$$

\subsection{Thermodynamic Analysis of Thermal Energy Storage}

244 Thermodynamic analysis of thermal energy storage has been performed under actual environmental 245 conditions during the charging, storing, and discharging phase. Equations for energy and exergy 246 parameters have been reduced as presented in Table 5, and these are analyzed in conjunction with the 247 performance of ET-CPC.

Table 5 Thermodynamic Analysis of Thermal Energy Storage

Thermodynamic Analysis of Thermal Energy Storage

Eq. No.

TES charging stage (Rezaie et al. 2015)

Energy Balance (Dincer and Rosen 2007)(Rosen and Dincer 2003)

$$
\begin{aligned}
& Q_{i n, T E S}-Q_{\text {loss }, T E S}=\Delta U_{\text {charging }} \\
& \Delta U_{\text {charging }}=m_{\text {total }} C_{f} \Delta T_{m} \\
& m_{\text {charging }}=\frac{Q_{\text {in,TES }}}{C_{f}\left(T_{c, \text { in }}-T_{c, \text { out }}\right)}
\end{aligned}
$$


Energy Efficiency

$$
\eta_{\text {charging }}=\frac{\text { Energyaccumulated inTES }}{\text { EnergyInput }}=\frac{\Delta U_{\text {charging }}}{Q_{\text {in,TES }}}
$$

\section{Exergy Balance}

$$
\begin{aligned}
& E x_{c, \text { in }}=m_{\text {charging }}\left[\left(h_{c, \text { in }}-h_{c, \text { out }}\right)-T_{\text {amb }}\left(s_{c, \text { in }}-s_{c, \text { out }}\right)\right] \\
& E x_{c, \text { loss }}=Q_{\text {loss }, T E S}\left(1-\frac{T_{a m b}}{T_{m}}\right) \\
& E x_{c, \text { accum }}=E x_{c, f}-E x_{c, i}=m_{\text {total }}\left[\left(u_{c, f}-u_{c, i}\right)-\left(s_{c, f}-s_{c, i}\right)\right]
\end{aligned}
$$

Exergy Destruction

$$
\Delta E x_{\text {charging }}=E x_{c, \text { in }}-E x_{c, \text { loss }}-E x_{c, \text { accum }}
$$

Exergy Efficiency

$$
\psi_{\text {charging }}=\frac{\text { Exergyaccumulated inTES }}{\text { Exergy Input }}=\frac{E x_{c, \text { accum }}}{E x_{c, \text { in }}}
$$

\section{TES Storing Stage}

Energy Efficiency

$$
\eta_{\text {storing }}=\frac{\text { Energy Accumulation in TES during ch } \arg \text { ing and storing }}{\text { Energy Accumulation in TESduring ch arg ing }}
$$

Exergetic Efficiency

$$
\psi_{\text {storing }}=\frac{\text { Exergy Accumulation in TES during ch } \arg \text { ing and storing }}{\text { Exergy Accumulation in TES during ch arg ing }}
$$

\section{TES Discharging Stage}

Energy recovered

$$
\begin{aligned}
& Q_{\text {rec }}=-\left(\Delta U_{\text {discharge }}+Q_{\text {loss }, T E S}\right) \\
& \Delta U_{\text {discharge }}=m_{\text {total }} C_{f} \Delta T_{m} \\
& m_{\text {discharging }}=\frac{Q_{\text {rec }}}{C_{f}\left(T_{d, \text { out }}-T_{d, \text { in }}\right)}
\end{aligned}
$$

Energy Efficiency

$$
\eta_{\text {discharging }}=\frac{\text { Energyre covered byTES }}{\text { Energy released byTES }}=\frac{Q_{\text {rec }}}{Q_{\text {rec }}+Q_{\text {loss }, T E S}}
$$


Exergy recovered

$$
E x_{\text {rec }}=m_{\text {discharge }}\left\lfloor\left(h_{d, \text { out }}-h_{d, \text { in }}\right)-T_{\text {amb }}\left(s_{d, \text { out }}-s_{d, \text { in }}\right)\right\rfloor
$$

Exergy accumulation

$$
\left.E x_{d, a c c u m}=E x_{d, f}-E x_{d, i}=m_{\text {total }} \mid\left(u_{d, f}-u_{d, i}\right)-\left(s_{d, f}-s_{d, i}\right)\right]
$$

Exergy destruction

$$
\Delta E x_{\text {discharging }}=E x_{d, \text { in }}-E x_{d, \text { loss }}-E x_{d, \text { accum }}
$$

Exergy efficiency

$$
\psi_{\text {discharging }}=\frac{\text { Exergy re covered byTES }}{\text { Exergyaccumulated in } T E S}=\frac{E x_{\text {rec }}}{E x_{d, a c c u m}}
$$

\section{Overall Energy and Exergy efficiency}

$$
\begin{aligned}
& \text { Energy efficiency } \\
& \eta_{O, T E S}=\frac{\text { Energyre covered from TES during disch } \arg \text { ing }}{\text { EnergyinputtoTES during ch } \arg \text { ing }}=\frac{\sum Q_{\text {rec }}}{\sum Q_{i n, T E S}}
\end{aligned}
$$

Exergy efficiency

$$
\psi_{O, T E S}=\frac{\text { Exergy recovered from TES during disch } \arg \text { ing }}{\text { ExergyinputtoTES during ch } \arg \text { ing }}=\frac{\sum E x_{\text {rec }}}{\sum E x_{c, i n}}
$$

250 With the ever-increasing concern about the environmental impact and specifically global

251 warming due to greenhouse gases, it has become essential to evaluate and analyze the newly 252 designed and developed system environmentally before heading forward. The developed system

253 was weighed on an environmental impact basis which is quantified based on saving on carbon

254 dioxide emissions. The change resulted in significant savings in $\mathrm{CO}_{2}$ yearly and finally a lesser 255 carbon footprint.

256 The annual social cost of $\mathrm{CO}_{2}$ emission varies from one country to another. The cost of penalty

257 for $\mathrm{CO}_{2}$ emissions is calculated using the relation,

$$
\dot{Z}_{\text {env }}=m_{\mathrm{Co}_{2}} \cdot C_{\mathrm{CO}_{2}}
$$


259 In above equation $C_{\mathrm{CO}_{2}}$ is the cost of unit carbon dioxide production and it varies from 0.022

$2601.63 \mathrm{INR} / \mathrm{kg}$ to $9.62 \mathrm{INR}$ per $\mathrm{kg}$ of $\mathrm{CO}_{2}$ emissions. In our study, prices of developing countries

261 have been chosen which is $3.7 \mathrm{INR} / \mathrm{kg}$. Here $m_{\mathrm{Co}_{2}}$ is the mass of $\mathrm{CO}_{2}$ emission and has been

262 calculated using emission conversion factor as follows:

$263 m_{\mathrm{Co}_{2}}=\lambda$. Power consumption in $\mathrm{kWh}$

264 Where, $\lambda$ is the emission conversion factor having a value of $0.968 \mathrm{~kg} / \mathrm{kWh}$. It is essential to 265 mention that India's energy mix has been used to obtain the results. Here it is taken as $1 \mathrm{kWh}_{\mathrm{e}}$ 266 leading to $0.968 \mathrm{~kg}$ of $\mathrm{CO}_{2}$ production.

$267 \quad 3.5 \quad$ Economic Analysis

268 Whether cooling, heating, or power, every solar-based system has indirect benefits in terms of 269 environmental protection, lower health costs, and global climate benefits, but never a decision on 270 investment in renewable systems are made on this basis. Quite a few times, lawmakers provide 271 incentives that may attract investment when looking to these social benefits. However, any 272 system must sustain itself until its financial viability or beneficiary.

273 The fossil-based system is relatively cheaper in terms of initial cost but they have a higher 274 recurring cost including regular energy billing, maintenance cost, etc. whereas the Solar-based 275 system is characterized by a high initial cost and negligible operating cost. Therefore it is very 276 much needed that the life cycle cost approach has to be adopted when comparing the solar-based 277 systems with the conventional-based systems.

278 The concept of life cycle cost includes both the initial investment cost and year-to-year operating 279 cost in making economic decisions. The life cycle cost of any energy system is the total of the 280 following cost made in its life term: 
1. The initial capital cost includes the cost of equipment, installation and land cost (if any).

2. Its running cost throughout its life.

3. Interest cost, if money is invested through borrowing.

4. Periodic maintenance cost of equipment or any miscellaneous cost.

6. Salvage value, if any at the end of its life span.

287 The first cost includes all the costs of owning the equipment and normally is one time. It includes 288 the cost of equipment, installation cost, and the cost of land, if applicable. On the other hand, 289 operation and maintenance cost includes the cost incurred during the life cycle of the domestic 290 water heating system year on year for operating the system which includes recurring electricity 291 cost for operating the system. During the economic evaluation of any solar-based system, the 292 initial investment made has to be weighted over the intended benefits in terms of heat, power, or 293 cooling which the system is supposed to provide. Hence the present value of future anticipated 294 benefits needs to be evaluated. Various financial performance parameters are analyzed over here, 295 refer to Table 6.

\section{Simple payback period (SPBP)}

$$
\mathrm{SPBP}=\frac{C C}{C F}
$$

Discounted payback period (DPBP)

$$
D P B P=\frac{\ln \left(\frac{1}{1-\frac{C C * r}{C F}}\right)}{\ln (1+r)}
$$


Internal Rate of Return

$$
0=\sum_{n=1}^{N} \frac{C F_{n}}{(1+I R R)^{n}}+C I
$$

Levelized Cost of Heating ( $\mathrm{LCOH})$

$$
L C O H=\frac{T L C C}{E_{n}}\left[\frac{1-(1+i)^{-n}}{i}\right]
$$

297

\section{Results and Discussion}

\subsection{Experimental Validation of Analytical Model}

Figure 5 shows the schematic diagram of the setup discussed above. However, only a solar hot charging loop is considered in this present study. Data received from different RTD sensors, mass flow sensors, pyranometer, and ambient temperature thermocouple have been integrated into the data logger and then the performance of ET-CPC coupled with a hot storage tank is 304 discussed by

305 It is observed from this experimental validation that relative difference is within the range of 3-

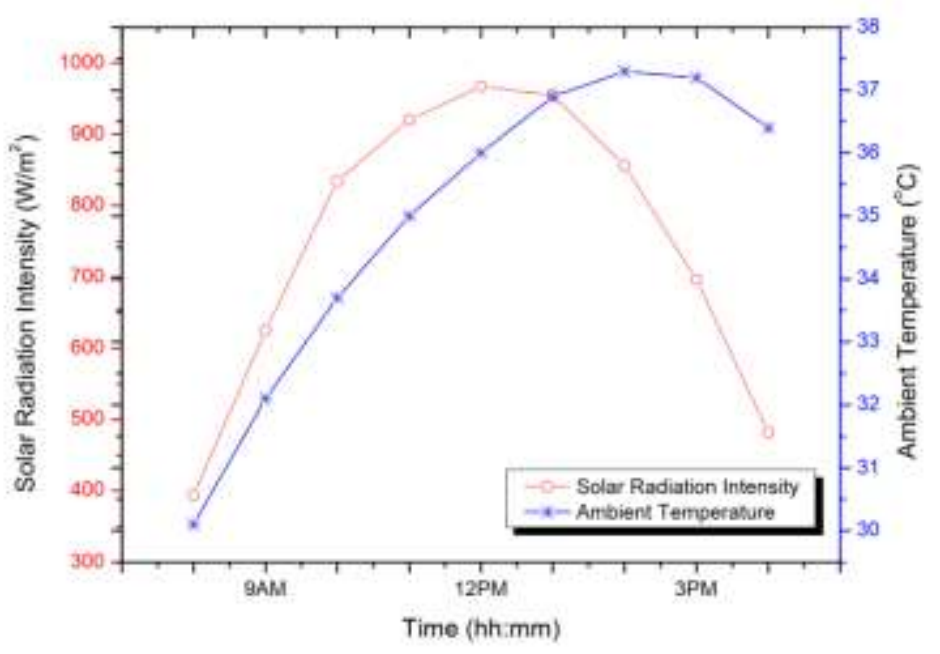




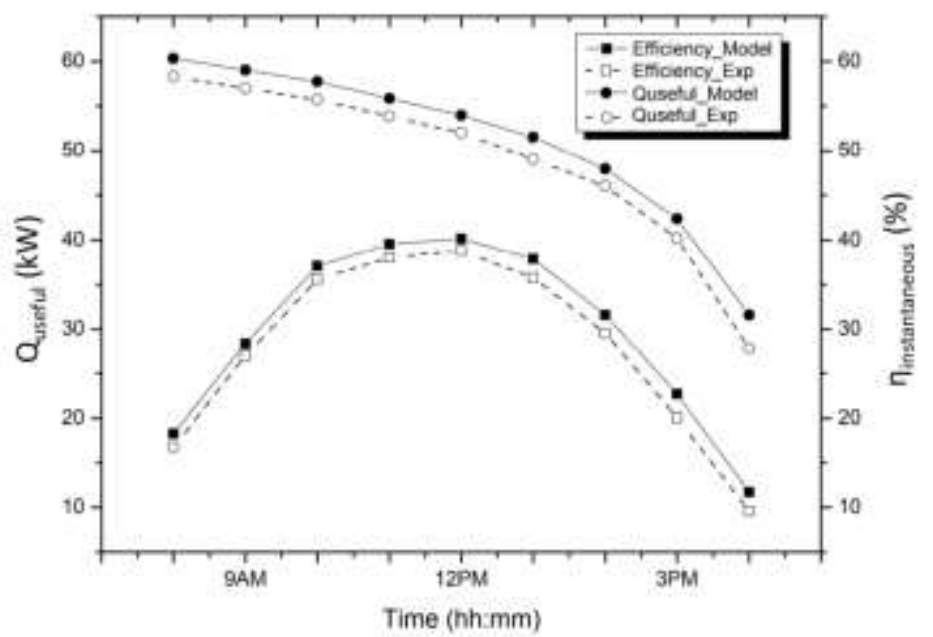

312 Figure 5 Experimental validation of analytical model on a typical day April 18, 2021 (a) Solar

313 radiation intensity and ambient temperature (b) efficiency and $\mathrm{Q}_{\text {useful }}$ model and experimental

\section{$314 \quad 4.2 \quad$ Parametric Analysis}

315 This parametric study shows the effect of mass flow rate, solar radiation intensity and ambient

316 temperature on the productivity and efficiency of the ET-CPC. A typical range of mass flow rate

317 is taken from 0.0132 to $0.0357 \mathrm{~kg} / \mathrm{s}$ through tubes of ET-CPC. The values of solar radiation

318 intensity are considered from 200 to $1000 \mathrm{~W} / \mathrm{m}^{2}$ varying in the steps of $100 \mathrm{~W} / \mathrm{m}^{2}$. The ambient

319 temperature values range from 27 to $43^{\circ} \mathrm{C}$. 


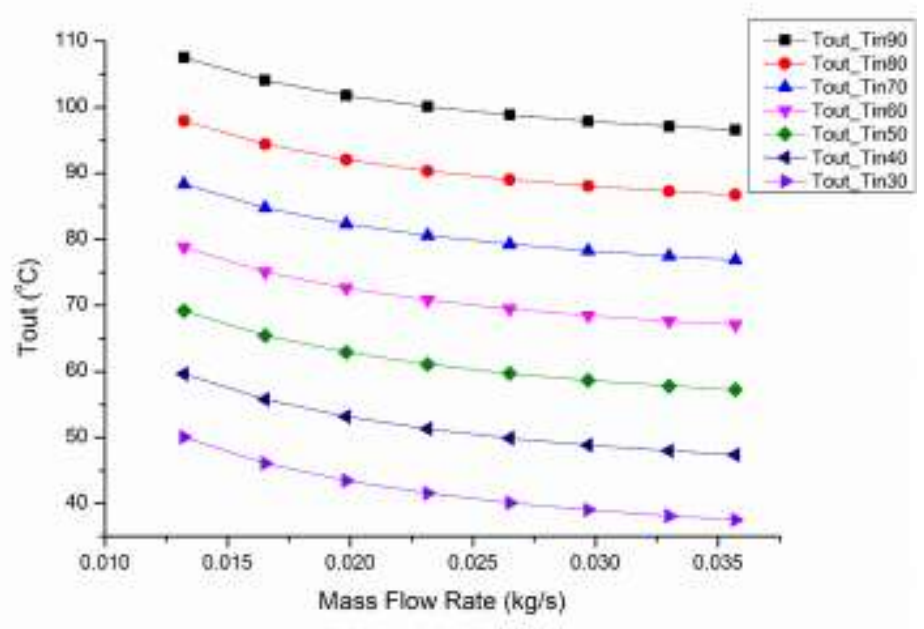

$322 \quad$ Figure 6 Effect of Mass Flow Rate on outlet temperature at a different inlet temperature

323 Figure 6 shows the variation of the system outlet temperature based on the mass flow rates. The 324 solar radiation intensity has been kept at $1000 \mathrm{~W} / \mathrm{m}^{2}$ while the ambient temperature is kept at $32527^{\circ} \mathrm{C}$. Inlet temperatures have been varied from 30 to $90^{\circ} \mathrm{C}$ within the steps of $10^{\circ} \mathrm{C}$. For the 326 different inlet temperatures, the slopes of the curves are declining in nature, which also supports 327 the theoretical knowledge. The slope of the curves decreases with the increase in inlet 328 temperature. The slope of the curve for $30^{\circ} \mathrm{C}$ is steepest and the slope of the curve for $90^{\circ} \mathrm{C}$ inlet 329 temperature is flattened. 




Figure 7 Effect of Mass Flow Rate on Quseful at different inlet temperatures

332 Figure 7 shows the effect of mass flow rate over the useful heat gain for various inlet 333 temperatures keeping solar radiation intensity $1000 \mathrm{~W} / \mathrm{m}^{2}$ and ambient temperature $27^{\circ} \mathrm{C}$. Useful 334 heat gain varies proportionally with the mass flow rate. $\mathrm{Q}_{\text {useful }}$ is higher for the lower inlet 335 temperatures and vice-versa. At $30^{\circ} \mathrm{C}$ inlet temperature, the useful heat gain is highest and for $33690^{\circ} \mathrm{C}$ inlet temperature, useful heat gain is lowest. This is since heat loss to the environment 337 increases as the inlet temperature increases and lowers as the mass flow rate increases.

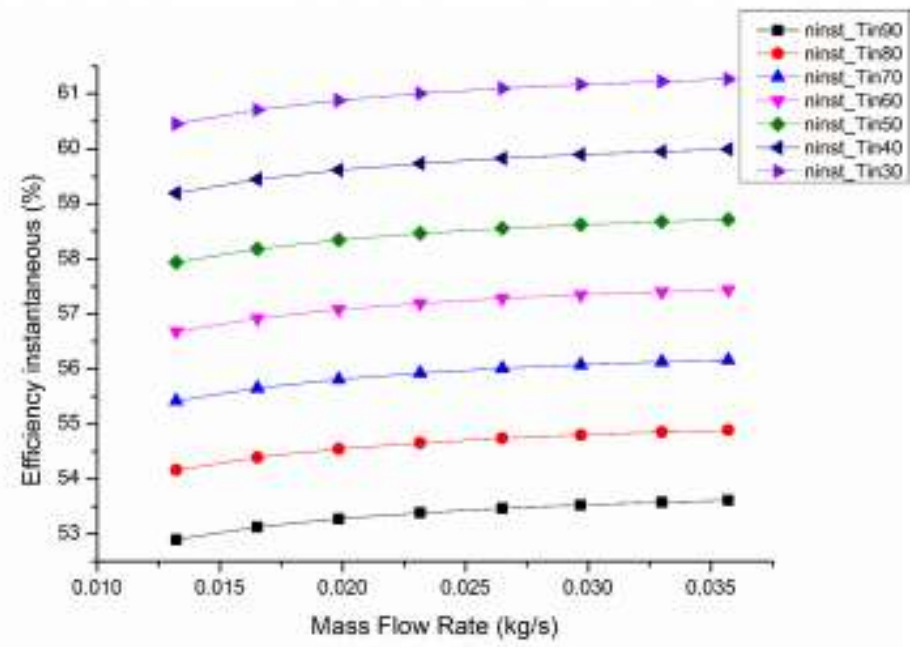

339 Figure 8 Effect of Mass Flow Rate on instantaneous efficiency with different inlet temperatures 
340 Figure 8 shows the effect of mass flow rate over instantaneous efficiency of ET-CPC for various

341 inlet temperatures at the solar intensity and ambient constant as described earlier. As the mass

342 flow rate increases, the system's instantaneous efficiency is also increases and vice-versa.

343 Instantaneous efficiency is better for lower inlet temperatures and reduces as temperature

344 increases. The highest instantaneous efficiency is recorded at inlet temperature at $30^{\circ} \mathrm{C}$ and mass

345 flow rate of $0.0357 \mathrm{~kg} / \mathrm{s}$.

346

347

348

349

350

351

352

353

354

355



Figure 9 Effect of Mass Flow Rate on Heat Removal Factor

The heat removal factor is an important design parameter as it is a measure of thermal resistance encountered by the absorbed solar radiation is reaching the collector fluid. Figure 9 shows the effect of mass flow rate on the heat removal factor. This can be concluded that there is an increasing trend for heat removal factor, however, this increase in heat removal factor is not significant thus an average value of 0.5635 is taken for further evaluation.

\subsubsection{Effect of solar radiation intensity}

The effect of solar radiation intensity is quite essential to assess as an operating parameter since it is the base for any type of solar energy projects without which proper sizing and economics of 
356 solar energy projects cannot be estimated. The effect of solar radiation intensity on outlet

357 temperature is shown in Figure 10. The solar radiation intensity is ranging from 200 to $1000 \mathrm{~m}^{2}$

358 taking fluid inlet temperature of $27^{\circ} \mathrm{C}$ and a constant mass flow rate of $0.0357 \mathrm{~kg} / \mathrm{s}$. There is an

359 obvious increase in the fluid outlet temperature corresponding to the increase in the solar

360 radiation intensity. However, as the inlet temperature increases, the outlet temperature increases

361 proportionally with the solar radiation intensity.

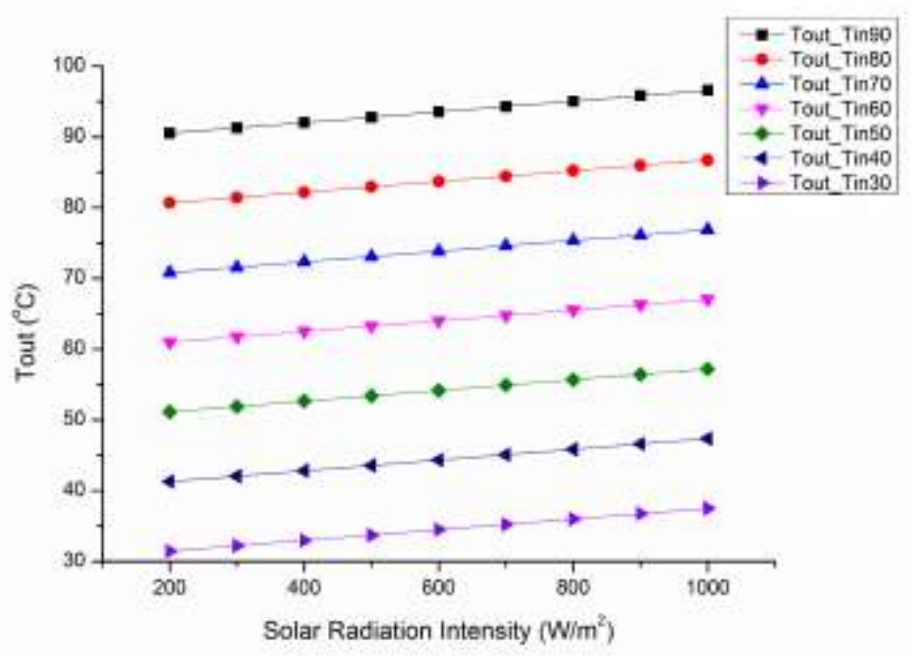

Figure 10 Variation of the outlet temperature as a function of the solar radiation intensity for various inlet temperatures

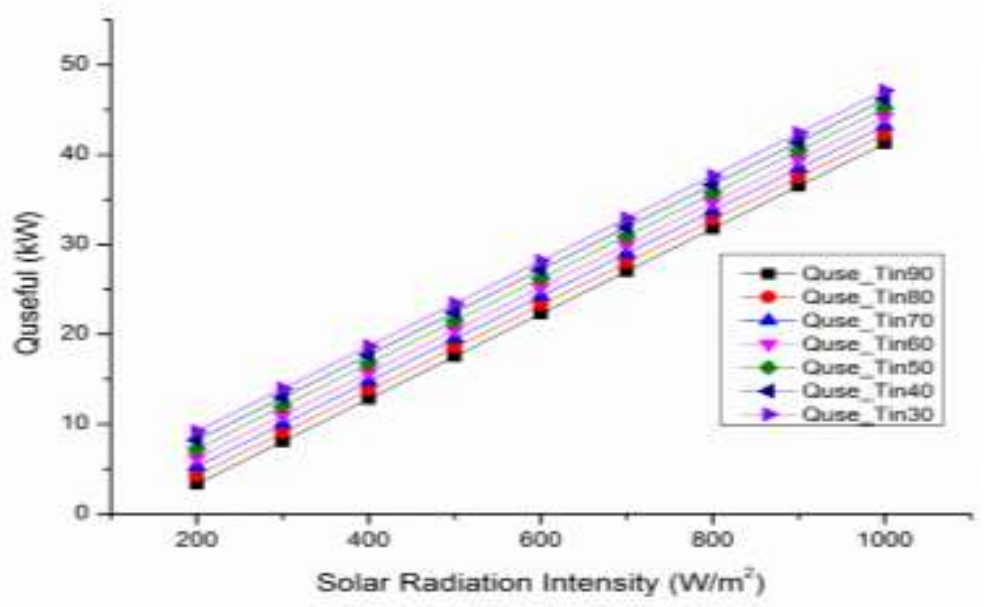

Figure 11 Effect of solar radiation intensity on useful heat gain 
367 Figure 11 shows that solar radiation intensity's effect on useful heat gain for various inlet 368 temperatures ranging from $30^{\circ} \mathrm{C}$ to $90^{\circ} \mathrm{C}$. As mentioned earlier, while showing this mass flow 369 rate is kept as $0.0357 \mathrm{~kg} / \mathrm{s}$, and ambient temperature is taken as $27^{\circ} \mathrm{C}$. It can be noted from the 370 figure that useful heat gain is directly proportional to the solar radiation intensity. For $30^{\circ} \mathrm{C}$ inlet

371 temperature, the useful heat gain is highest and lowers as the inlet temperature increases. Useful 372 heat gain is ranges between 40-46 kW for a given system's solar radiation intensity of 1000 $373 \mathrm{~W} / \mathrm{m}^{2}$.

374

375

376

377

378

379

380

381



Figure 12 Effect of solar radiation intensity on instantaneous efficiency

Figure 12 represents the effect of solar radiation intensity on instantaneous efficiency for various inlet temperatures as discussed earlier. The instantaneous efficiency usually increases with the increase in the solar radiation intensity. The highest instantaneous efficiency was observed at $30^{\circ} \mathrm{C}$ inlet temperature at solar radiation intensity of $1000 \mathrm{~W} / \mathrm{m}^{2}$. As the inlet temperature of fluid increases, instantaneous efficiency decreases. This is mainly because of higher heat losses to the environment at higher inlet temperatures. However, these relative differences reduce at the 
382 higher value of solar radiation intensity. Further, it can be observed that instantaneous efficiency

383 is still in the range of $40-50 \%$ which is significantly better than any other stationary STC.

\section{$384 \quad$ 4.2.3 Effect of Ambient Temperature}

385 The effect of ambient temperature on productivity is reported in this section. The solar radiation intensity is considered as $1000 \mathrm{~W} / \mathrm{m}^{2}$ along with a constant mass flow rate of $0.0357 \mathrm{~kg} / \mathrm{s}$. Figure

38713 shows the effect of ambient temperature over fluid outlet temperature for various inlet 388 temperatures. It is observed that there is no significant variation observed in the fluid outlet 389 temperatures with ambient temperatures. Hence it can be concluded from this discussion that 390 ambient is the least dominant factor which affects the productivity of ET-CPC and further, useful 391 heat gain and instantaneous efficiency.

392

393

394

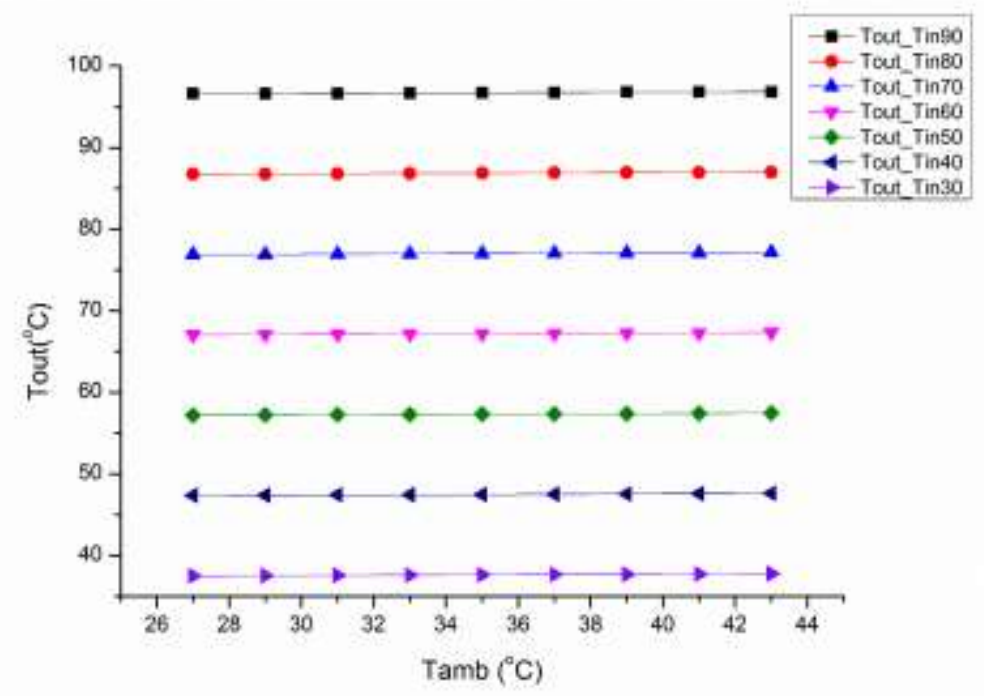

Figure 13 Effect of ambient temperature on Outlet temperature with different inlet temperatures 4.3 Evaluation of Useful energy and exergy gain under actual meteorological conditions

As mentioned earlier, four meteorological conditions of Rajasthan (India) have been considered. Data have been recovered using the TMY2 file for these identified locations. The information has been used in the model to evaluate the variation of productivity and efficiency for the stated 
ET-CPC powered SDWH system with the help of various indicators of energy and exergy analysis such as useful heat gain, instantaneous efficiency, exergy gain, and exergetic efficiency.

400 The results have been shown in stack form altogether to have a better and direct comparison of 401 these identified indicators.

402

403

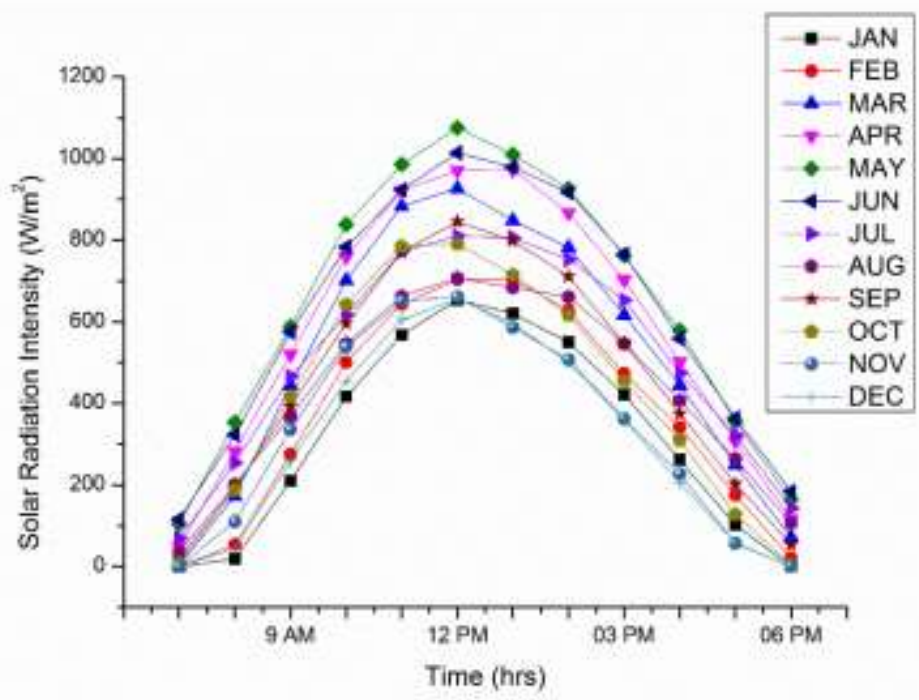

(a)

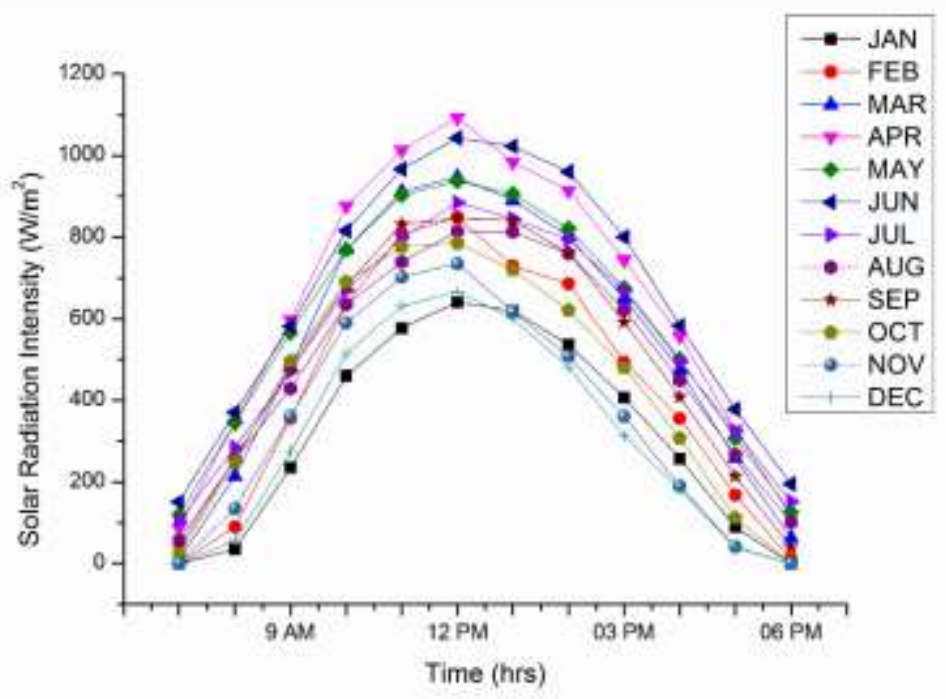

(b) 


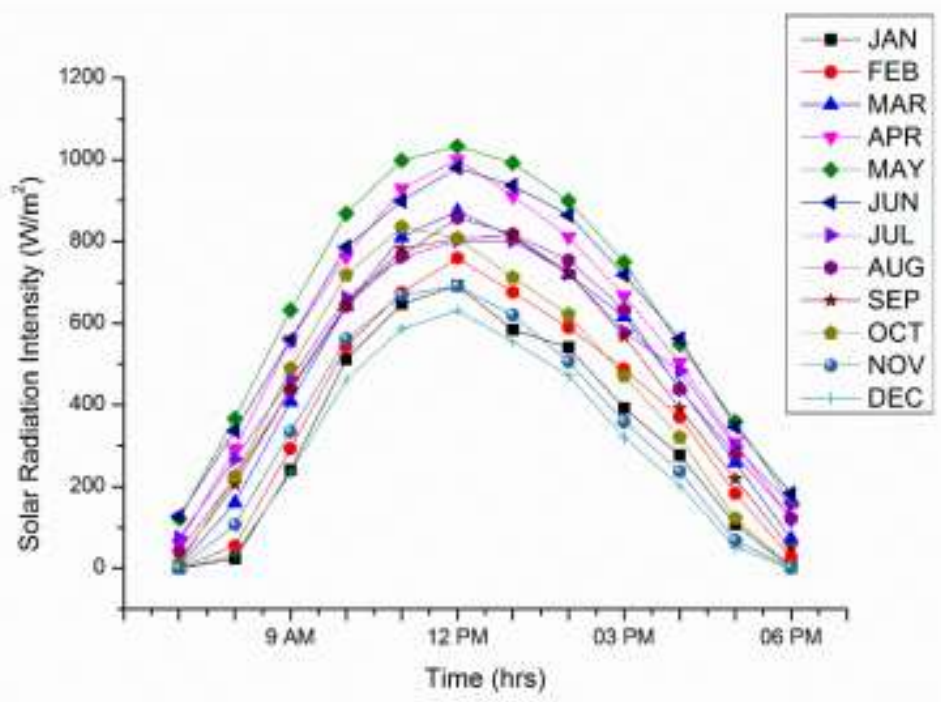

(c)



411 Figure 14 (a), (b), (c) and (d) shows the solar radiation intensity variation for year-round at

412 Barmer, Jodhpur, Jaisalmer, and Jaipur respectively. The highest solar radiation intensity data are

413 recorded between April and June while the lowest is recorded between November and January.

414 The highest solar intensity is observed around 12 PM for nearly every month. The highest value 
415 of solar intensity is recorded as 1075, 1093, 1033 and $985 \mathrm{~W} / \mathrm{m}^{2}$ for Barmer, Jodhpur, Jaisalmer and Jaipur respectively.

417
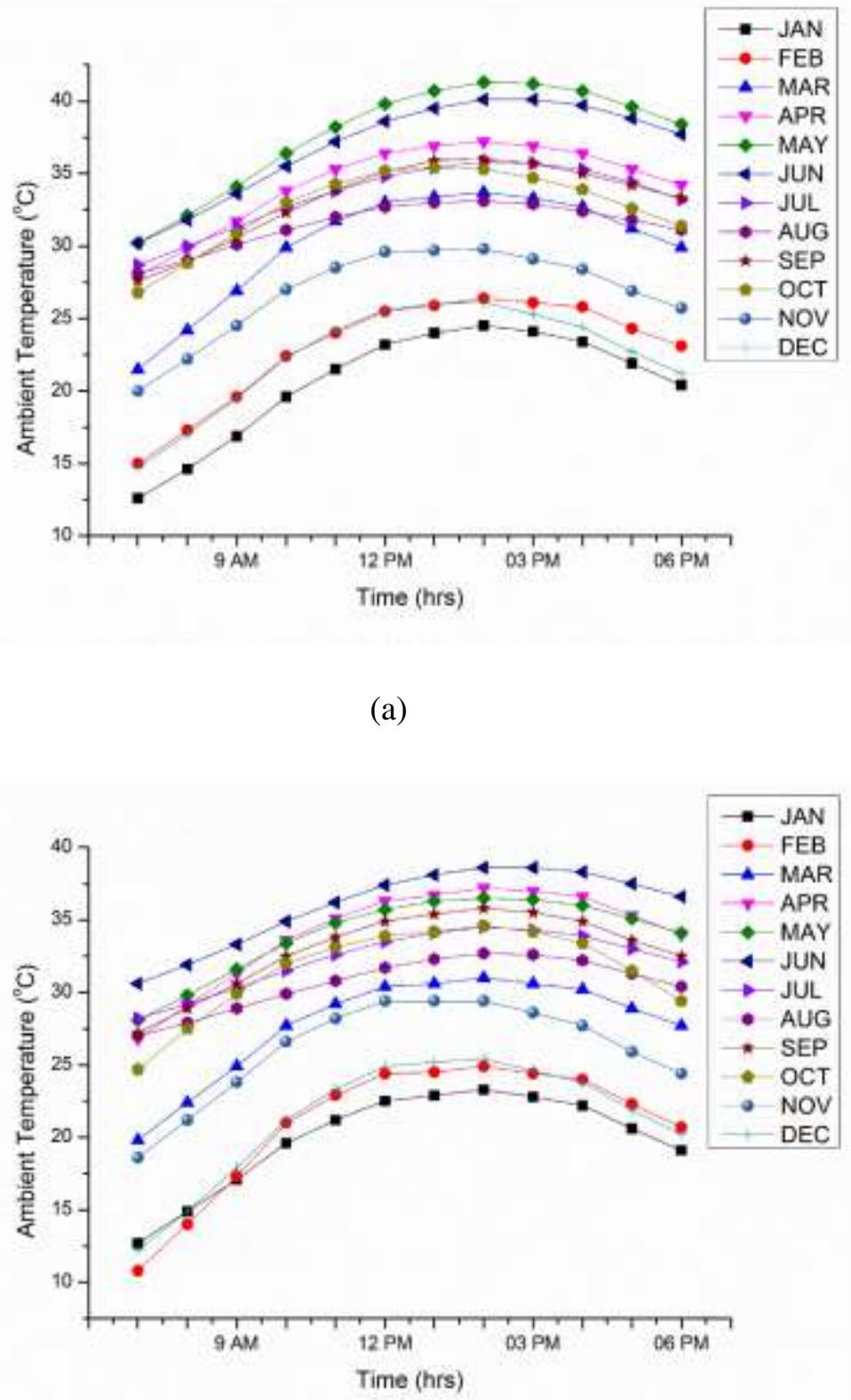

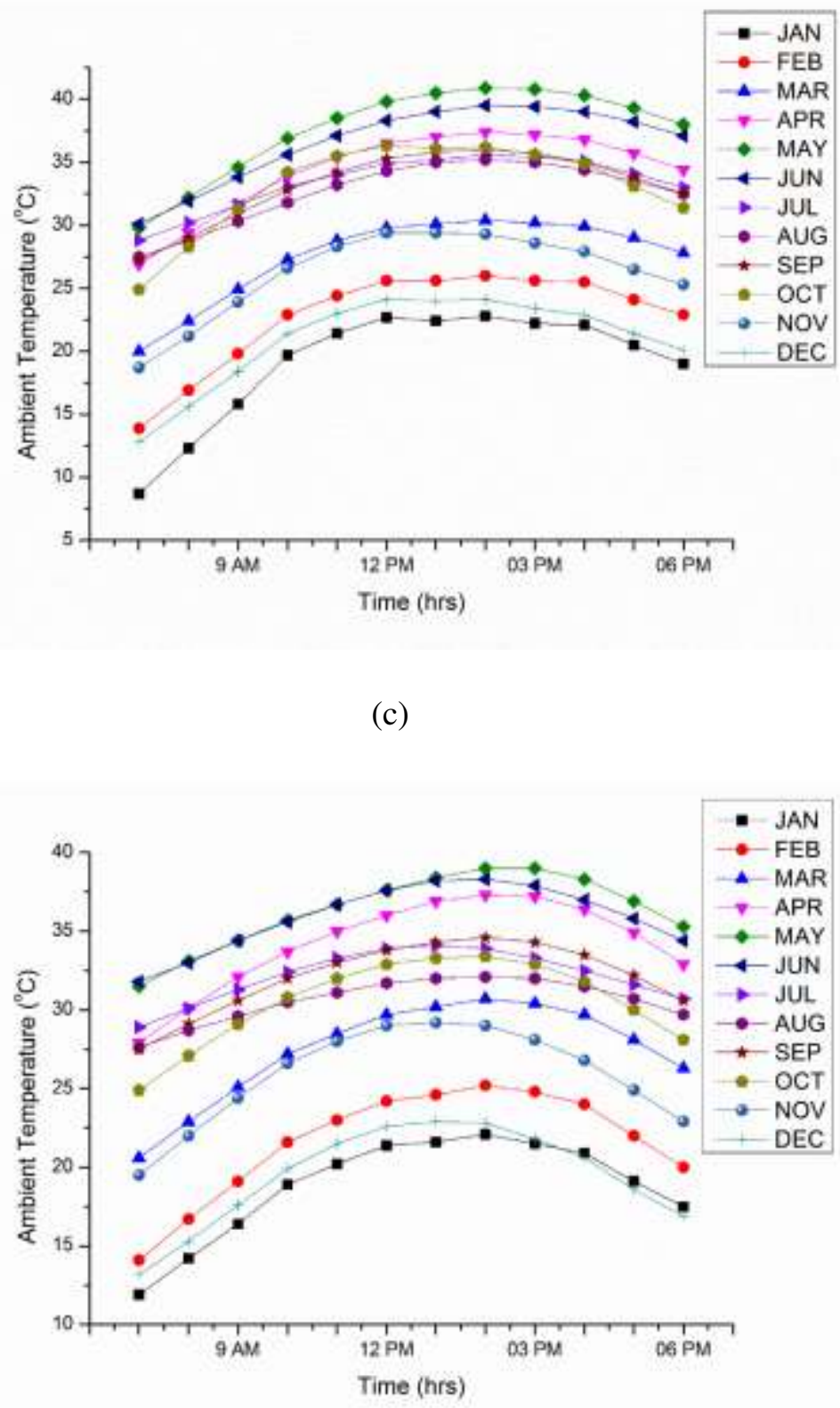

(d)

Figure 15 Ambient temperature curves for (a) Barmer (b) Jodhpur (c) Jaisalmer (d) Jaipur

426 Figure 15 (a), (b), (c), and (d) shows the variation of ambient temperature around the year for

427 Barmer, Jodhpur, Jaisalmer and Jaipur respectively. It is observed that the highest ambient

428 temperature achieved in the month may and lowest ambient temperature in the month January 429 around $2 \mathrm{PM}$. ]The highest ambient temperature was recorded as $41.3,38.5,40.9$ and $39^{\circ} \mathrm{C}$ for 
430 Barmer, Jodhpur, Jaisalmer and Jaipur respectively while the lowest temperature recorded was

$43115^{\circ} \mathrm{C}$ for Jaisalmer for a specified time of the day. The warmest months are May, June and July

432 for all specified locations while the coldest months are December, January and February.

\section{$433 \quad$ 4.3.1 Energy Analysis}

434 Figure 16 (a) shows a comparison analysis between the solar radiation intensity, useful heat gain 435 and instantaneous efficiency under the meteorological condition of Barmer for the different436 different months of a typical meteorological year (TMY). Similarly, Figures 16 (b), (c) and (d) 437 are showing useful heat gain, instantaneous efficiency and solar radiation intensity for different 438 months at locations Jodhpur, Jaisalmer and Jaipur respectively. The curve shows that the highest 439 solar radiation intensity $1075 \mathrm{~W} / \mathrm{m}^{2}$ measured in May month. Similarly, the useful heat gain 440 curve also has a higher value of $45.03 \mathrm{~kW}$ during April and May. It is observed from the Figure 441 that the solar radiation intensity and $\mathrm{Q}_{\text {useful }}$ are greater in the summer season months. But the 442 instantaneous efficiency curve shows the higher values for the winter months. It is mainly 443 because of the higher temperature difference between the inlet and outlet fluid in winter and 444 efficiency is directly proportional to this temperature difference so the instantaneous efficiency is 445 higher in December and January.

446 The highest value was measured as $67.25 \%$ in January. Similarly, the highest solar radiation 447 intensity comes $1093 \mathrm{~W} / \mathrm{m}^{2}$ for Jodhpur followed by 1033 and $985 \mathrm{~W} / \mathrm{m}^{2}$ for Jaisalmer and 448 Jodhpur locations during April and May. Accordingly, the $\mathrm{Quseful}_{\mathrm{u}}$ is measured higher for April, 449 May and June. The highest value of $\mathrm{Q}_{\text {useful }}$ is recorded as $46.02 \mathrm{~kW}$ for Jodhpur followed by 45042.86 and $40.67 \mathrm{~kW}$ for Jaisalmer and Jaipur respectively during April and June. However, as 451 discussed earlier, the highest instantaneous efficiency of $66.64 \%$ for Jodhpur is recorded during 452 January followed by 67.14 and $66.53 \%$ for Jaisalmer and Jodhpur respectively. 


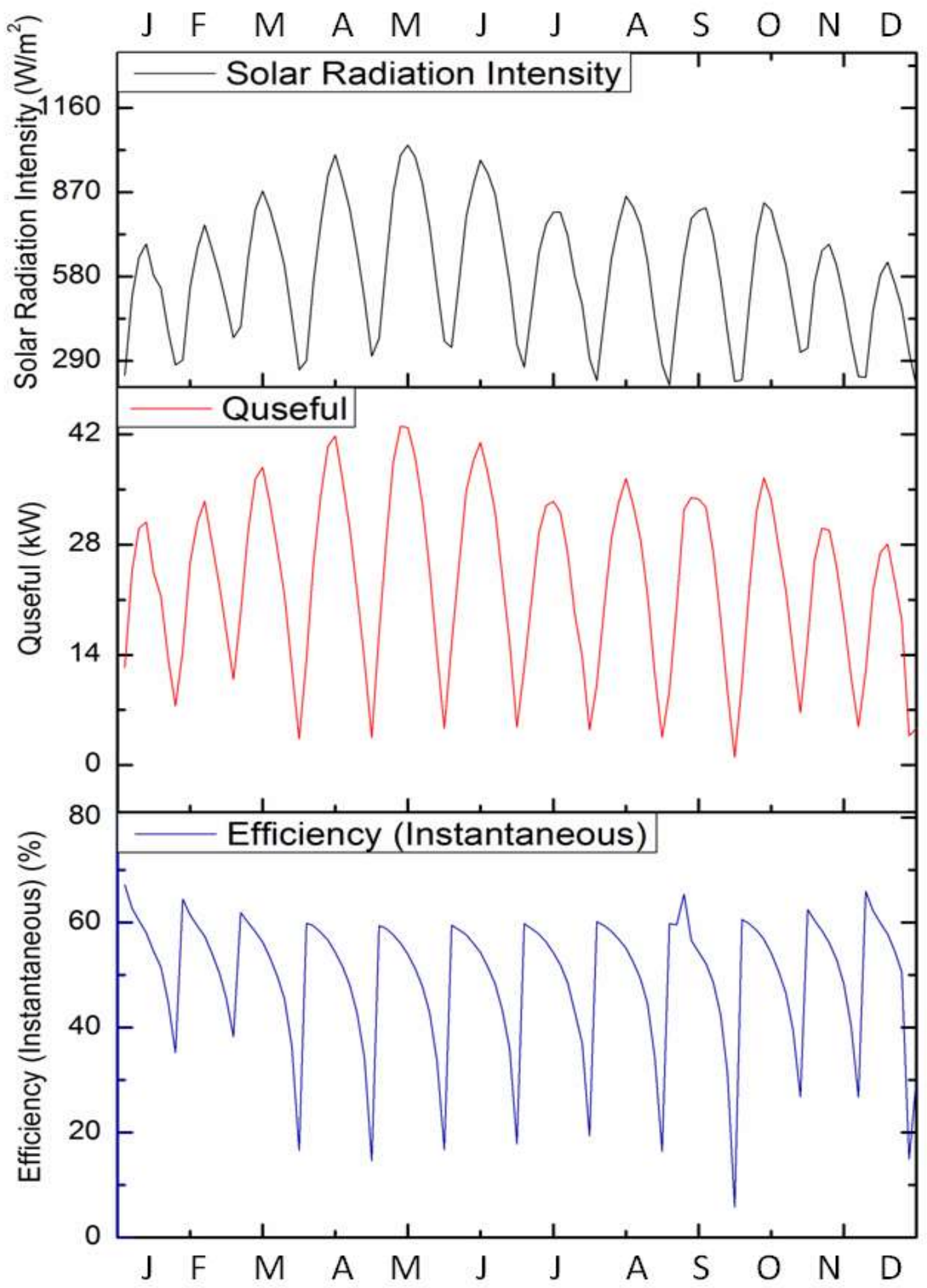




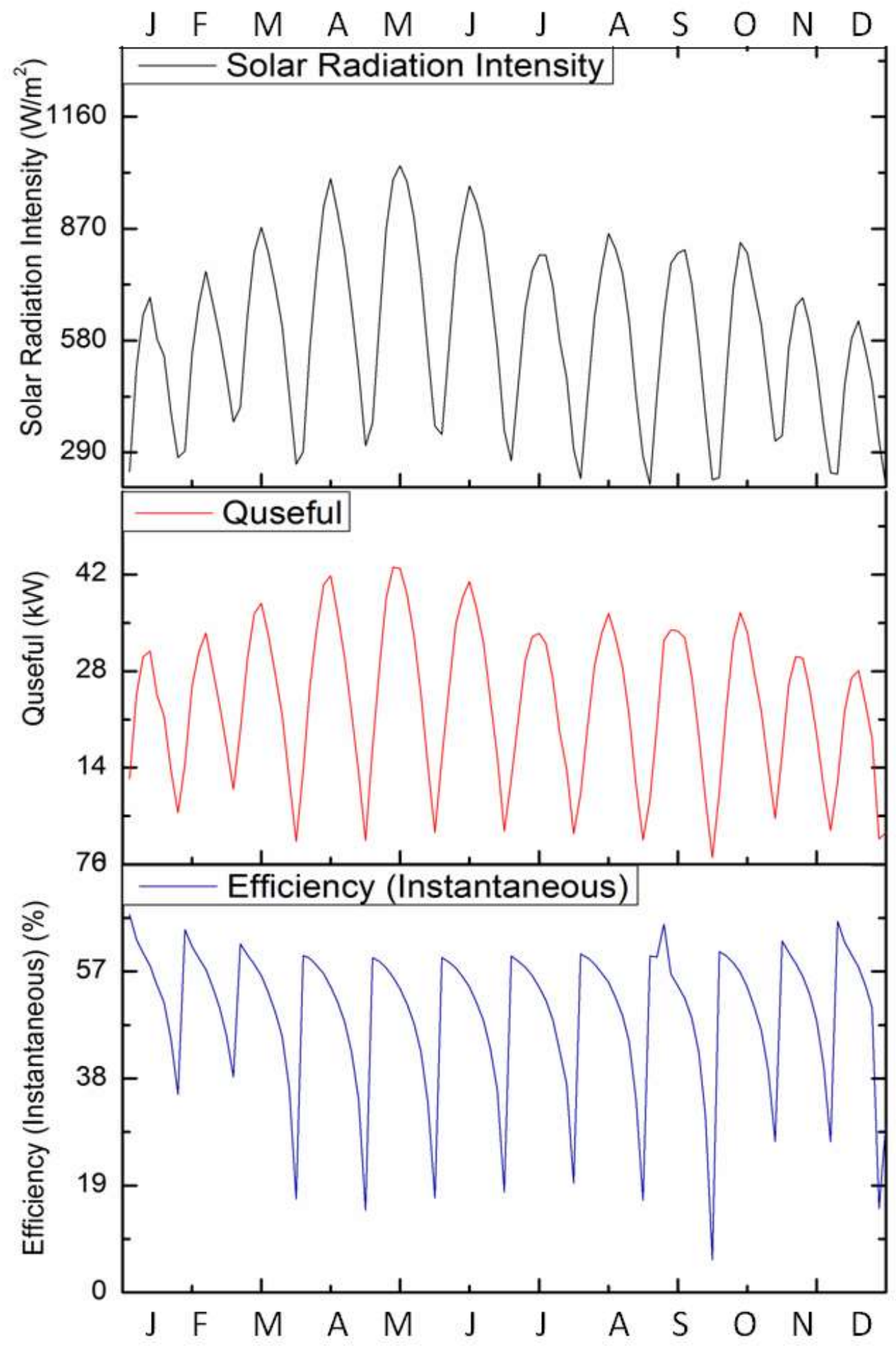




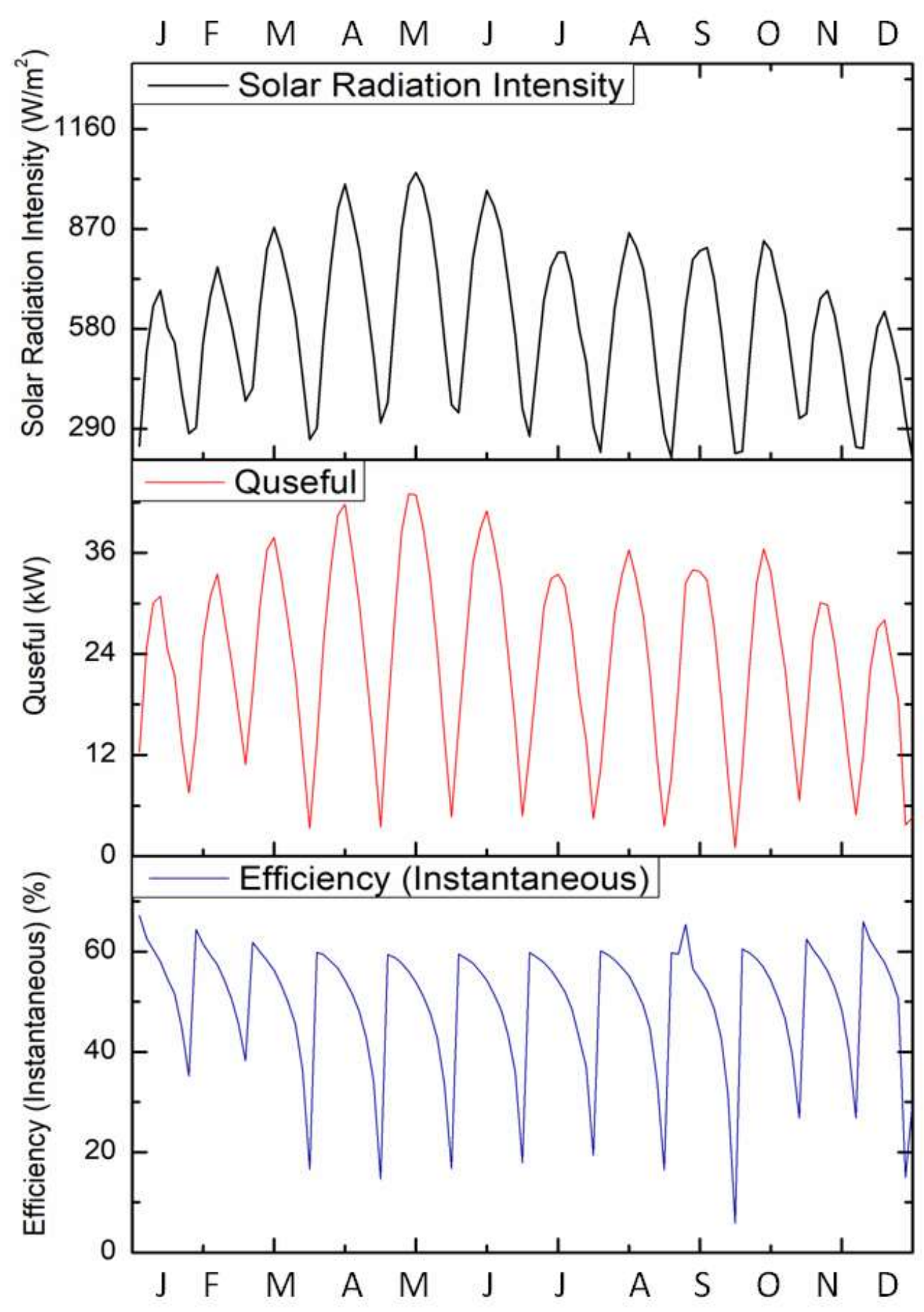




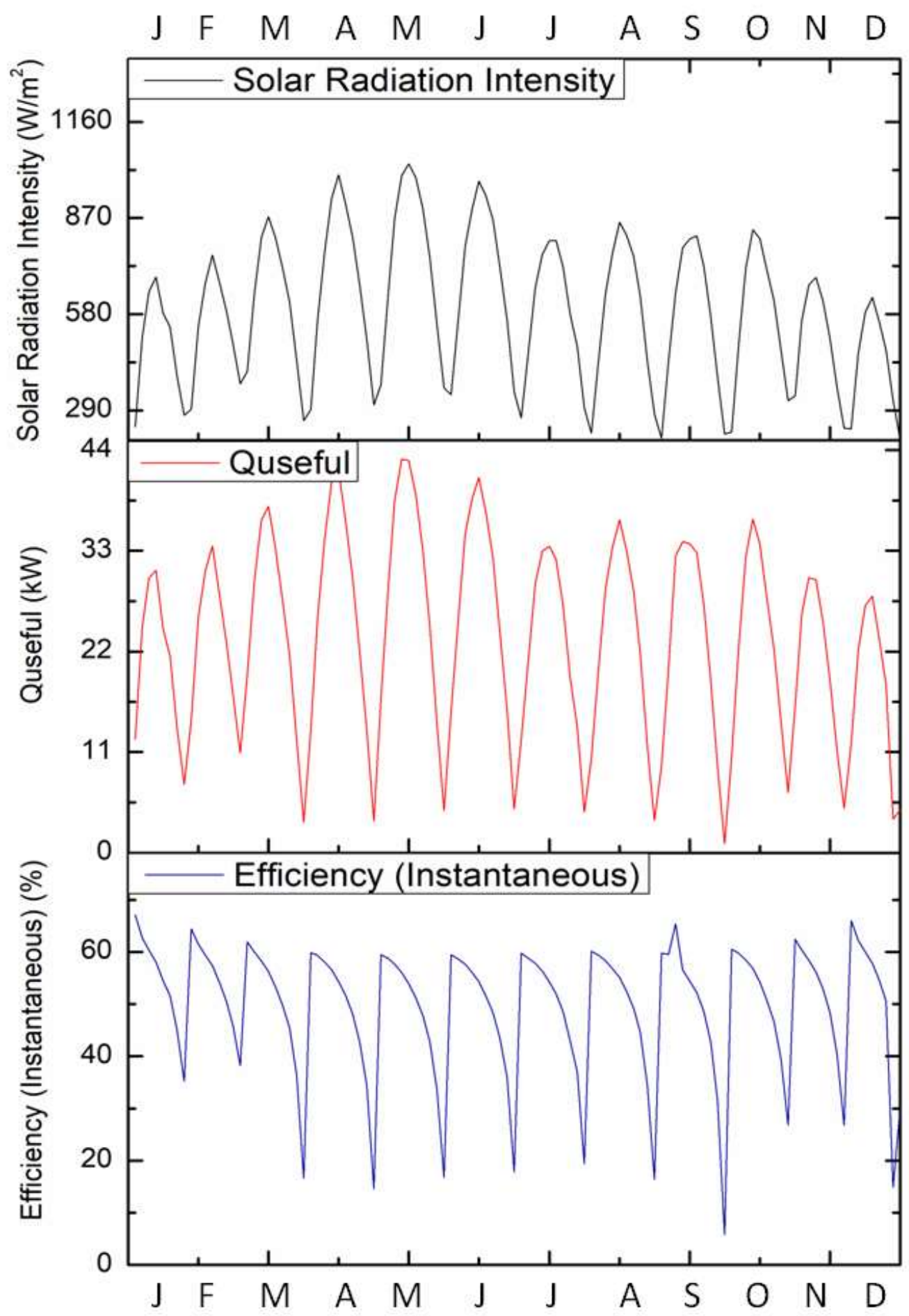

459

(d)

461 Figure 16 Parameters indicating Energy Analysis under meteorological condition of (a) Barmer 


\section{$463 \quad$ 4.3.2 Exergy analysis}

464 Figure 17 (a), (b), (c) and (d) manifests the exergy analysis consisting of three parameters as 465 amount of exergy inlet, amount of useful exergy and exergetic efficiency for various months 466 under the meteorological conditions of Barmer, Jodhpur, Jaisalmer and Jaipur respectively. The

467 first part of the curves elucidates the exergy variation in other months. The maximum exergy in 468 measured as $80.74 \mathrm{~kW}$ during May month. This curve also illustrates that the amount of exergy 469 is higher in the summer season and lower in the winter season. It is mainly because of the higher 470 solar radiation intensity in summers as compared to the winters. The second and third parts of 471 these curves illustrate the behavior of exergy gain and exergetic efficiency for different specified

472 locations during different months. The highest value of exergy gain is observed during April and 473 June. It is observed as $7.50 \mathrm{~kW}$ for Jodhpur followed by $7.33,7.17$ and $7.09 \mathrm{~kW}$ for Barmer, 474 Jaisalmer and Jaipur respectively during May. The exergetic efficiency is observed as $10.57 \%$ 475 for Barmer during May. Since the amount of exergy useful is higher and subsequently exergetic 476 efficiency is also higher. The highest exergetic efficiency is again recorded for Jodhpur as 11. $477 \quad 05 \%$ during June. The highest exergetic efficiency for Jaisalmer and Jaipur is recorded as 10.58 478 and $10.55 \%$ respectively. 


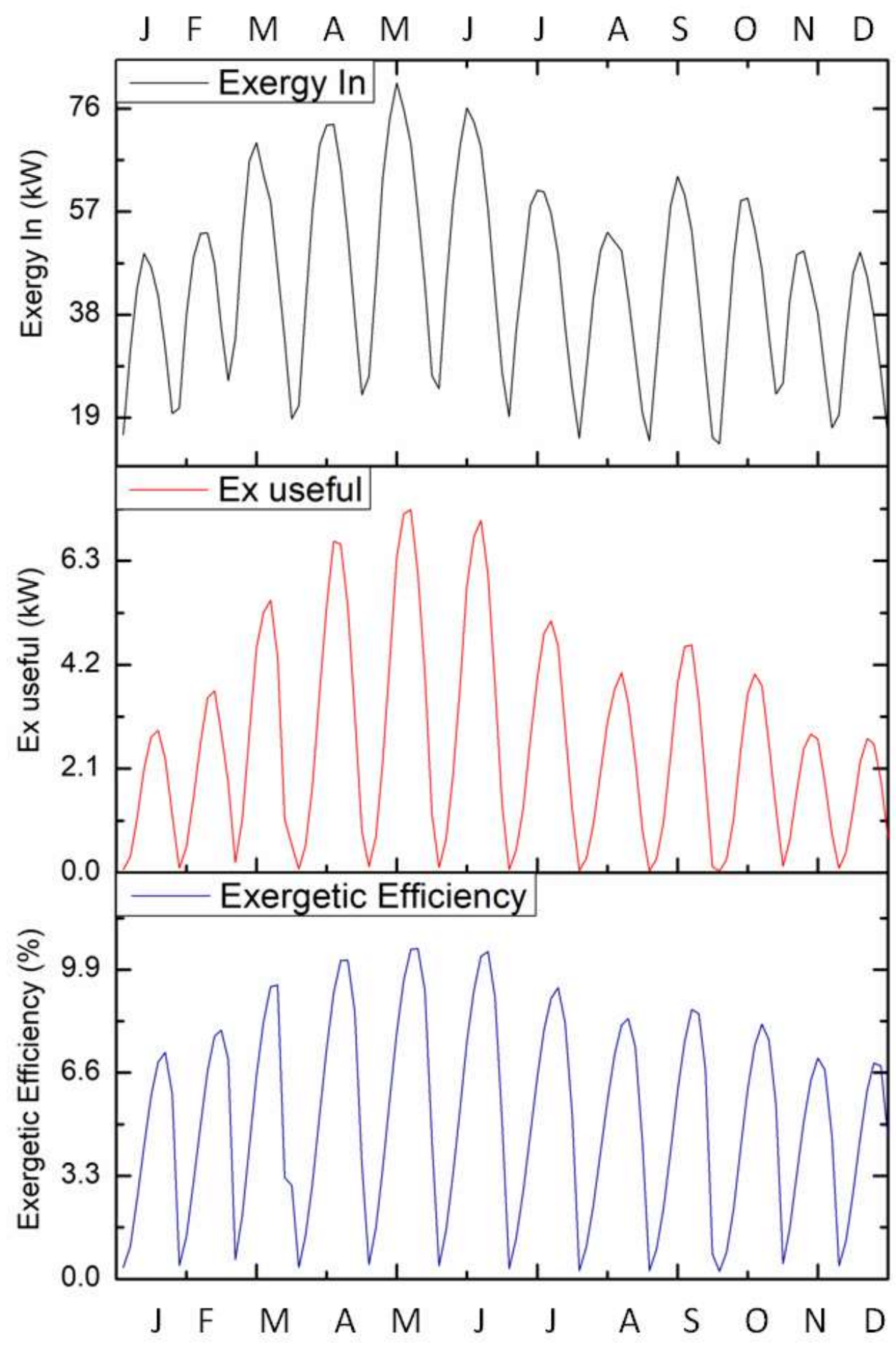




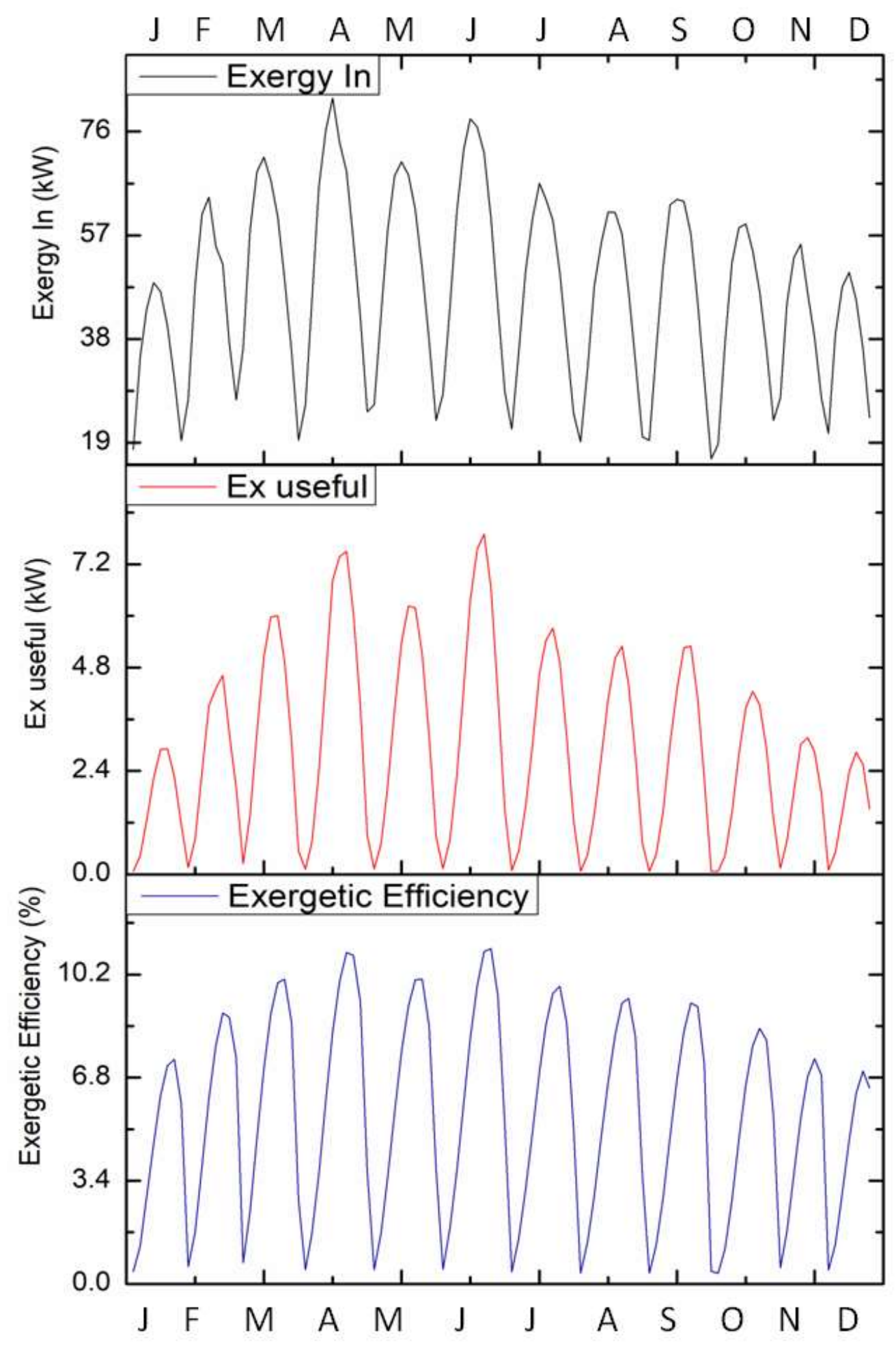




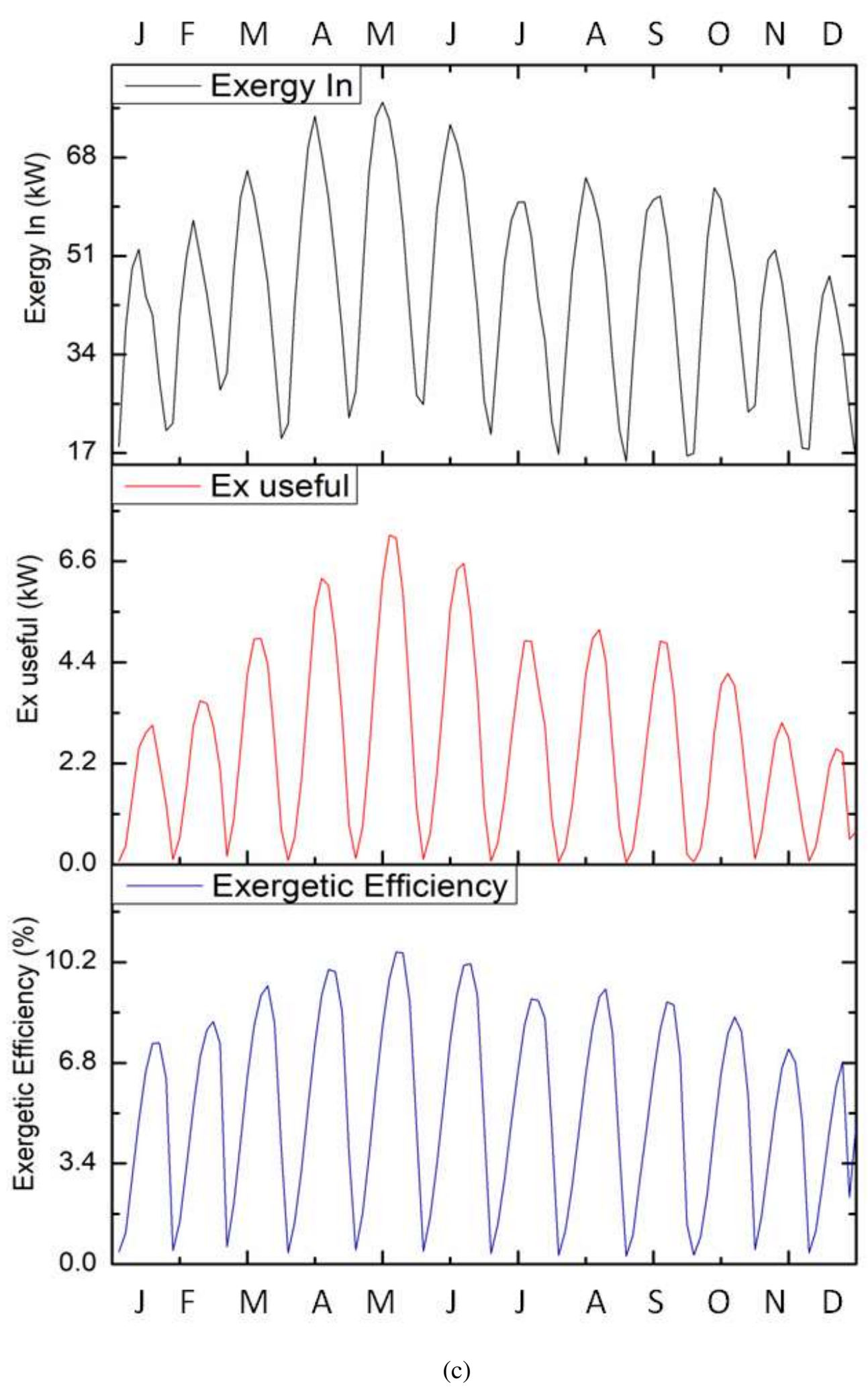




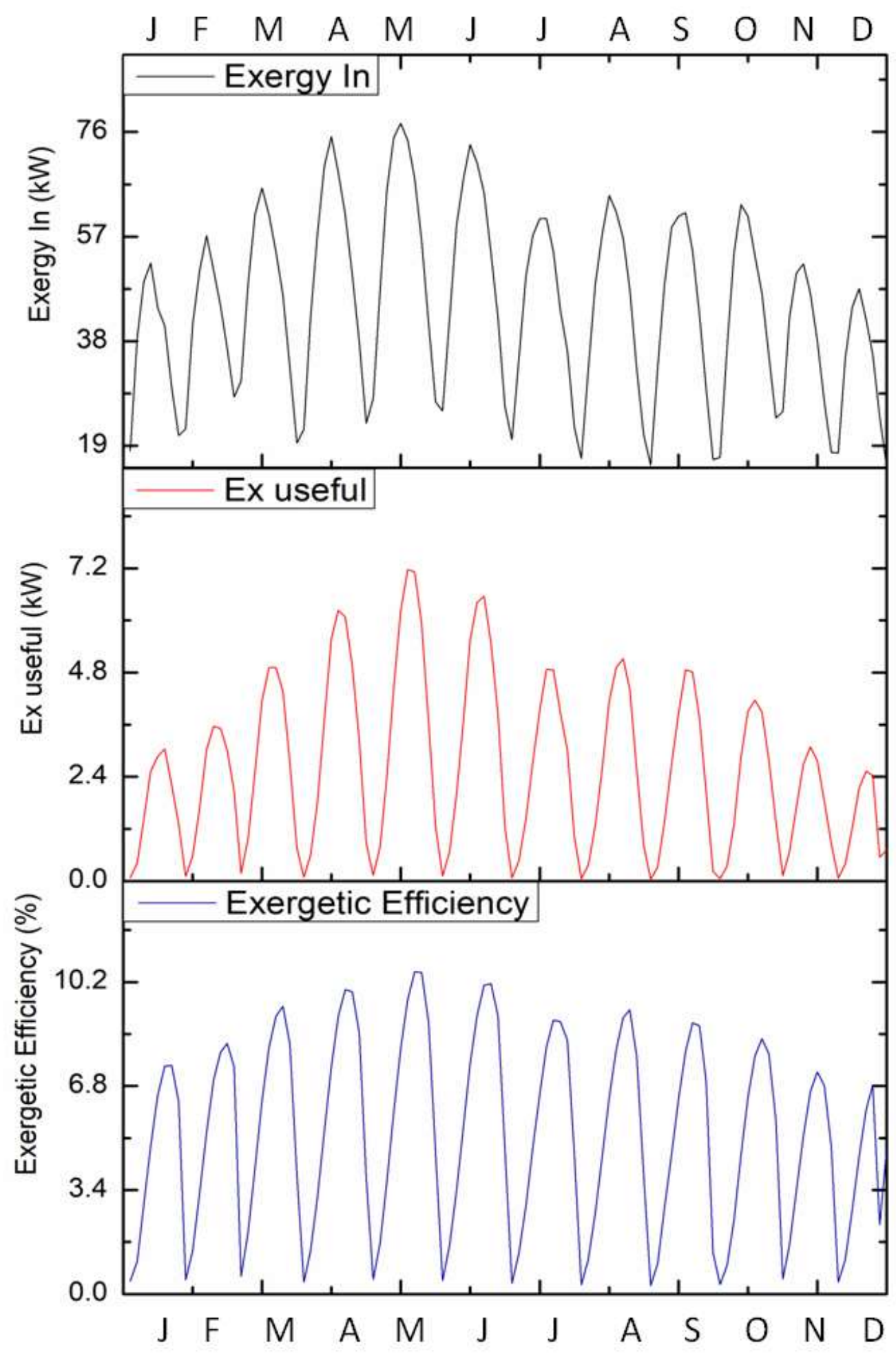

(d)

487 Figure 17 Parameters indicating Exergy Analysis under meteorological condition of (a) Barmer 488 (b) Jodhpur (c) Jaisalmer (d) Jaipur 
489 However, a comparison is essential to discuss site selection to indicate the annual useful heat 490 gain and useful exergy gain for all specified locations. Figure 18 shows the comparison of solar 491 energy received by the ET-CPC solar field, useful heat gain, exergy inlet and exergy gain annual 492 for the specified locations Barmer, Jodhpur, Jaipur and Jaisalmer. As observed Jodhpur is having 493 the most excellent solar radiation $162 \mathrm{MWh} /$ year and thus highest annual useful energy and 494 exergy gain as reported to be $79.72 \mathrm{MWh}$ and 9.311 MWh annually. Jaisalmer receives 157.85 $495 \mathrm{MWh}$ of solar radiation per year which is getting converted to $76.90 \mathrm{MWh} / \mathrm{year}$ of useful heat 496 gain. Exergy gain calculated for Jaisalmer is 8.53 MWh concerning inlet Exergy of 146.63 MWh 497 per year. Similarly for useful heat gain is as 75.92 and $75.32 \mathrm{MWh} /$ year for Barmer and Jaipur 498 respectively. Exergy gain for Barmer and Jaipur is calculated as 8.4 and 8.32 MWh/year 499 respectively.

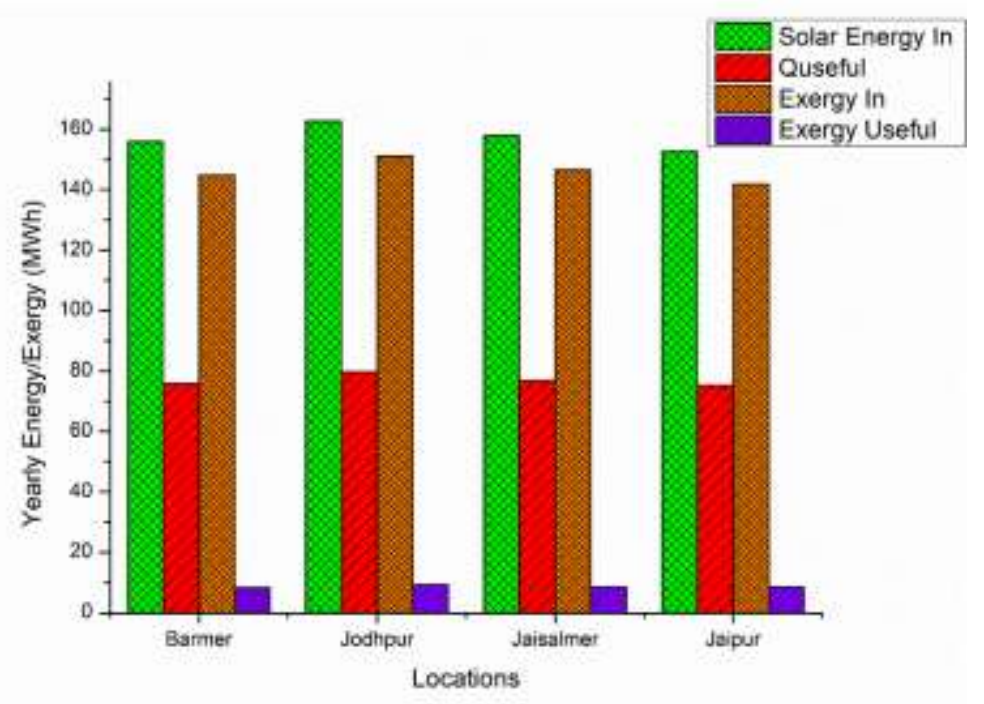

501 Figure 18 Solar energy-exergy graph comparison for four different meteorological condition

\section{$502 \quad 4.4 \quad$ Environmental Impact Analysis}

503 The use of solar energy is always helpful to overcome $\mathrm{CO}_{2}$ emission-related environmental 504 impact issues such as global warming, smog, acid rain and rise in mean global ambient 
temperature. This analysis reports the massive savings of $\mathrm{CO}_{2}$ emission compared to the other existing conventional solar water heating systems. Figure 19 represents the $\mathrm{CO}_{2}$ emission saved

507 in $\mathrm{kg}$ of $\mathrm{CO}_{2}$ for various identified locations.

508

509

510

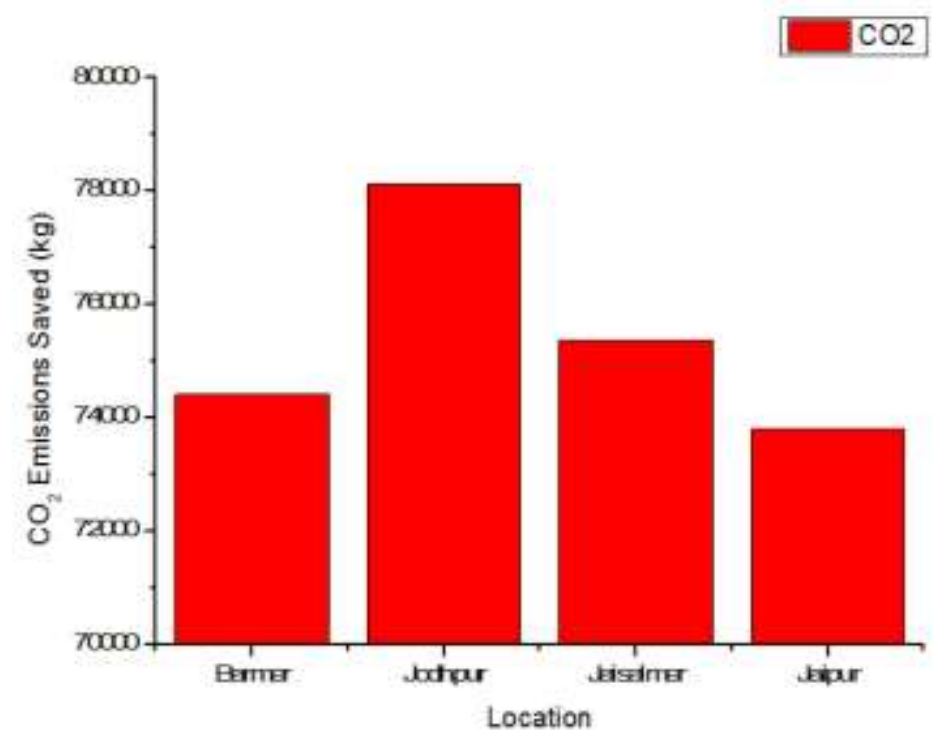

Figure 19 Comparison of $\mathrm{CO}_{2}$ emission saved with the use of solar energy for identified locations

\subsection{Economic Analysis}

As discussed earlier, economic analysis is quite an essential to compare different existing technologies based on profitability. A detailed economic analysis has been reported here to understand the effect of location on cost recovery and other indicators of economic profitability.

There are five conventional fuels-based water heating systems for the economic comparison with the existing solar water heating system. Table 7 shows the different fuels used for water heating and their corresponding price, conversion efficiency and calorific value of fuels.

Table 7 Comparison of price, conversion efficiency and calorific values for various fuels

\begin{tabular}{llcccc}
\hline Sr. No. & Fuel & Units & Price & Conversion Efficiency & CV Fuel (MJ/kg) \\
\hline $\mathbf{1}$ & Electricity & per kWh & 9.84 & 0.9 & 3.6 (MJ/unit) \\
2 & LPG & per kg & 86.34 & 0.6 & 55 \\
\hline
\end{tabular}




\begin{tabular}{llllll}
\hline $\mathbf{3}$ & Karosene & per kg & 67.68 & 0.4 & 45 \\
$\mathbf{4}$ & Fuelwood & per kg & 10 & 0.25 & 22 \\
$\mathbf{5}$ & Natural gas & per kg & 34.2 & 0.6 & 50 \\
\hline
\end{tabular}
Table 8 shows the installation cost or first cost of the different water heating systems. It can be easily identified that the first cost of a solar water heating system is significantly higher than

521 those of other systems. Table 9 reports the annual operation and maintenance cost of various

522 fuels while Table 10 shows the estimated life expectancy of the selected systems. Economic 523 evaluation is done based on equations reported in Table 6. Table 11 describes the internal rate of 524 return and payback periods. The internal rate of return is $16.82 \%$ for Jodhpur followed by 16.77 , 52516.76 and 16.75 for Jaipur, Barmer and Jaisalmer respectively. Similarly simple payback period 526 is $4.49,4.65,4.72$ and 4.75 years for Jodhpur, Jaipur, Barmer and Jaisalmer respectively. The 527 discounted payback period is also calculated which is ranging from 6.6 to 7.09 years similarly 528 for identified locations.

Table 8 Comparison of First Cost for various water heating systems

\begin{tabular}{ll}
\hline System & First Cost in INR \\
\hline ET-CPC Solar Water Heating & 947520 \\
Electricity based Water Heater & 250000 \\
LPG/Kerosene/CNG operated water heaters & 226762 \\
Firewood operated water heater & 250000 \\
\hline
\end{tabular}

Table 9 O\&M cost for various locations for different fuels

\begin{tabular}{|c|c|c|c|c|c|c|c|c|c|}
\hline \multirow[t]{2}{*}{$\begin{array}{l}\text { Sr. } \\
\text { No. }\end{array}$} & \multirow[t]{2}{*}{ Fuel } & \multirow[t]{2}{*}{ Units } & \multirow[t]{2}{*}{ Price } & \multirow[t]{2}{*}{$\begin{array}{l}\text { Conversion } \\
\text { Efficiency }\end{array}$} & \multirow[t]{2}{*}{$\begin{array}{l}\text { CV Fuel } \\
\text { (MJ/kg) }\end{array}$} & \multicolumn{4}{|c|}{$\underline{\text { O\&M Cost (INR) }}$} \\
\hline & & & & & & Barmer & Jodhpur & Jaipur & Jaisalmer \\
\hline 1 & Electricity & per & 9.84 & 0.9 & 3.6 & 830043 & 871598 & 873202 & 823490 \\
\hline
\end{tabular}




\begin{tabular}{lllrrrrrrr}
\hline & & unit & \multicolumn{7}{c}{ (MJ/unit) } \\
$\mathbf{2}$ & LPG & per kg & 86.34 & 0.6 & 55 & 715074.16 & 750875.4 & 724408.3 & 709432.2 \\
$\mathbf{3}$ & Kerosene & per kg & 67.68 & 0.4 & 45 & 1027639.6 & 1079090 & 1041054 & 1019532 \\
$\mathbf{4}$ & Fuelwood & per kg & 10 & 0.25 & 22 & 496924.36 & 521803.6 & 503410.9 & 493003.6 \\
$\mathbf{5}$ & Natural & per kg & 34.2 & 0.6 & 50 & 311571.58 & 327170.9 & 315638.6 & 309113.3 \\
& gas & & & & & & & & \\
\hline
\end{tabular}

\begin{tabular}{llll}
\hline & IRR $(\%)$ & SPBP $($ Yr $)$ & DPBP $($ Yr $)$ \\
\hline Barmer & 16.76 & 4.7169 & 7.024 \\
Jodhpur & 16.82 & 4.492 & 6.615 \\
Jaipur & 16.77 & 4.656 & 6.912 \\
Jaisalmer & 16.75 & 4.7543 & 7.093 \\
\hline
\end{tabular}

Table 10 Life expectancy of equipment

\begin{tabular}{ll}
\hline Expected Life (Solar System) & $\mathbf{1 5}$ years \\
\hline Expected Life (Electricity heating system) & 15 years \\
Expected Life (LPG/CNG/Kerosene fired heating system) & 15 years \\
Discount Rate & $6 \%$ annual \\
\hline
\end{tabular}

Table 11 Comparison of IRR and payback periods for identified locations for solar water heating system

537 A comparison of operation and maintenance costs has been presented in Figure 20. The kerosene 538 fuel-operated water heating system shows the highest cost of operation and maintenance, 539 followed by Electricity and LPG. This can be seen that solar energy is having significantly less 540 operation and maintenance costs as compared to that of other conventional fuels reported. 




541

542 Figure 20 Comparison of Annual O\&M cost for various fuels used for domestic water heating 543 system

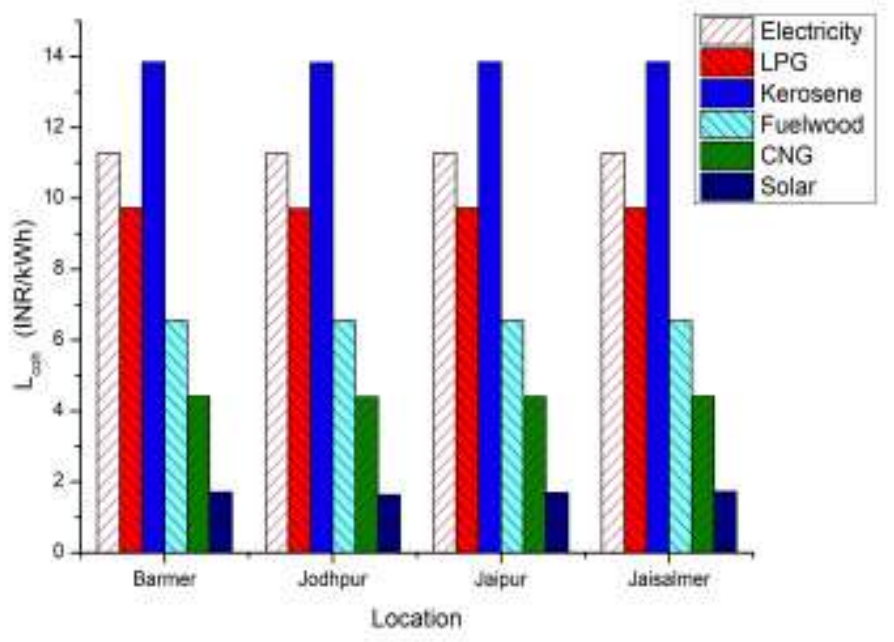

Figure 21 Comparison of Levelized cost of Heating for various fuels for identified locations

547 Levelized cost of Heating is essentially a significant indicator to compare overall cost per unit

$548 \mathrm{kWh}$ of Heating. It can be seen from Figure 21, LCOH is significantly less in the case of ET-

549 CPC solar water heating system ranging from $1.65 \mathrm{INR} / \mathrm{kWh}$ to $1.72 \mathrm{INR} / \mathrm{kWh}$ followed by

550 Kerosene (13.83 INR/kWh) and Electricity (11.25 INR/kWh). SPBP and DPBP are calculated as 
$551 \quad 4.5-4.75$ year and 6.6-7 year respectively taking a discount rate of $6 \%$. The internal rate of return 552 is reported to be $16.76,16.82,16.77$ and $16.75 \%$ for Barmer, Jodhpur, Jaipur and Jaisalmer 553 respectively which proved that it is a very profitable business model, refer to Table 11.

\section{5. Conclusion}

555 An SDWH powered by an $81 \mathrm{~m}^{2}$ ET-CPC solar collector field is reported in presented here. 556 Energy, exergy, environmental and economic analysis is carried out. The following points are 557 drawn as the conclusion of this work.

558 - The developed model results are validated with the experimental results and relative 559 differences are ranged from 3 to $8 \%$.

560 Parametric analysis shows that with the increase in mass flow rate ranging from 0.0132 to $5610.0357 \mathrm{~kg} / \mathrm{s}$, there is simultaneous improvement in the useful heat gain and instantaneous 562 efficiency of ET-CPCs. However, there is a drop in the useful heat gain and instantaneous 563 efficiency with an increase in the inlet temperature which ranged from $30-90^{\circ} \mathrm{C}$.

564 - Effect of solar radiation intensity ranging from $200-1000 \mathrm{~W} / \mathrm{m}^{2}$ has been reported for various inlet temperatures to evaluate and compare the useful heat gain and instantaneous efficiency of ET-CPC solar field.

- It has also been reported that there is no significant effect of ambient temperature over the useful heat gain and efficiency.

- The analytical model is then implemented under meteorological conditions of four specified locations (Barmer, Jodhpur, Jaisalmer and Jaipur), then annual energy and exergy gain have been evaluated and compared. Jodhpur is receiving the most excellent 
solar radiation and thus highest annual useful energy and exergy gain have been reported to be 79.72 MWh and 9.311 MWh followed by Jaisalmer, Barmer and Jaipur.

- The economic analysis reports the simple payback period ranging from 4.5 to 4.75 years and discounted payback period ranging from 6.6 to 7 years based on a $6 \%$ discount rate.

- Along with this, based on levelized cost of heating using solar energy as fuel is ranging from 1.62 to $1.72 \mathrm{INR} / \mathrm{kWh}$ of heat compared to closest with the use of CNG as fuel which is ranging from 4.39 to $4.41 \mathrm{INR} / \mathrm{kWh}$.

- The highest $\mathrm{LCOH}$ has been reported for electricity for domestic water heating which ranged from 11.25 to $11.27 \mathrm{INR} / \mathrm{kWh}$.

- The internal rate of return is reported to be $16.76,16.82,16.77$ and $16.75 \%$ for Barmer, Jodhpur, Jaipur and Jaisalmer respectively which proved that it is a very profitable business model.

- The environmental analysis also supports the previous trends and report 74400, 78125, 75371 and $73813 \mathrm{~kg}$ of $\mathrm{CO}_{2}$ saved which anyway got added to the environment if the electricity was used for the same purpose.

Hence it can be recommended that ET-CPC is a viable, economical and pollution-free alternative to meet the medium temperature heat demand such as in solar water heating systems for domestic and community use. ET-CPC operation is not possible during weak sunshine $(<200$ $\mathrm{W} / \mathrm{m}^{2}$ ) hours and technology advancement is needed in this direction. The use of nanofluids as a working fluid is reported to be advantageous to improve the productivity and performance of the ET-CPC further but insufficient data is there and that also reports operational issues. Research could be made to find the optimal configuration of nanofluids to offer less/no operational issues 
594 and optimal performance. Further, ET-CPC life cycle cost assessment could be worked out to

595 understand the overall impact on nature.

596 -Ethical Approval

597 We confirm that this work has not been published elsewhere, nor it is currently under 598 consideration for publication elsewhere.

599 -Consent to Participate

600 Authors give their consent to participate.

$601-$ Consent to Publish

602 We consent it to publish in the Environmental Science and Pollution Research after acceptance.

603 -Authors Contributions

604 Dinesh Kumar Sharma is a corresponding of this manuscript. He has involved in the 605 development of entire manuscript.

606 Prof. Dilip Sharma has involved in the conceptualization of this research and reviewed the 607 technical details of the manuscript.

608 Prof. Ahmed Hamza H Ali has involved in the conceptualization and reviewed the language and 609 grammar of the manuscript.

$610 \quad$-Funding

611 There are no funding disclosures to make.

$612 \quad$-Competing Interests

613 Authors have no conflict of interest to disclose.

614 -Availability of data and materials

615 Calculations data and other relevant material would be made available to editor/reviewer as and 616 when required. 


\section{References}

618 Battisti R, Corrado A (2005) Environmental assessment of solar thermal collectors with integrated water storage. Journal of Cleaner Production 13:1295-1300. doi: 10.1016/j.jclepro.2005.05.007

Bejan A, Kearney DW, Kreith F (1981) Second law analysis and synthesis of solar collector systems. Journal of Solar Energy Engineering Transactions of ASME 103:23-28. doi: 10.1115/1.3266200

Bellos E, Tzivanidis C, Tsifis G (2017) Energetic, Exergetic, Economic and Environmental (4E) analysis of a solar assisted refrigeration system for various operating scenarios. Energy Conversion and Management 148:10551069. doi: 10.1016/j.enconman.2017.06.063

Caliskan H (2017) Energy, exergy, environmental, enviroeconomic, exergoenvironmental (EXEN) and exergoenviroeconomic (EXENEC) analyses of solar collectors. Renewable and Sustainable Energy Reviews 69:488-492. doi.org/10.1016/j.rser.2016.11.203

Cengel YA, Boles MA (2019) Thermodynamics: An Engineering Approach 9th Editon (SI Units). McGraw Hill Publication. Newyork

Chopra K, Tyagi V V., Pandey AK, et al (2021) Energy, exergy, enviroeconomic \& exergoeconomic (4E) assessment of thermal energy storage assisted solar water heating system: Experimental \& theoretical approach. Journal of Energy Storage 35:102232. doi: 10.1016/j.est.2021.102232

Dincer I, Rosen MA (2007) Exergy: Energy, environment and sustainable development. John Wiley and Sons

Faizal M, Saidur R, Mekhilef S, et al (2015) Energy, economic, and environmental analysis of a flat-plate solar collector operated with SiO2nanofluid. Clean Technologies and Environmental Policy 17:1457-1473. doi: 10.1007/s10098-014-0870-0

Geete A, Dubey A, Sharma A, Dubey A (2019) Exergy Analyses of Fabricated Compound Parabolic Solar Collector with Evacuated Tubes at Different Operating Conditions: Indore (India). Journal of the Institution of Engineers (India) Series C 100:455-460. doi: 10.1007/s40032-018-0455-5

Hazami M, Kooli S, Naili N, Farhat A (2013) Long-term performances prediction of an evacuated tube solar water heating system used for single-family households under typical Nord-African climate (Tunisia). Solar Energy 94:283-298. doi: 10.1016/j.solener.2013.05.020

Jiang L, Widyolar B, Winston R (2015) Characterization of Novel Mid-temperature CPC Solar Thermal Collectors. In: Energy Procedia 70: 65-70. doi.org/10.1016/j.egypro.2015.02.098

Kabeel AE, Abdelgaied M, Elrefay MKM (2020) Thermal performance improvement of the modified evacuated Utube solar collector using hybrid storage materials and low-cost concentrators. Journal of Energy Storage 29:101394. doi: 10.1016/j.est.2020.101394

Kerme ED, Chafidz A, Agboola OP, et al (2017) Energetic and exergetic analysis of solar-powered lithium bromidewater absorption cooling system. Journal of Cleaner Production 151:60-73. doi:10.1016/j.jclepro.2017.03.060

Ma L, Lu Z, Zhang J, Liang R (2010) Thermal performance analysis of the glass evacuated tube solar collector with U-tube. Building and Environment 45: 1959-67. doi: 10.1016/j.buildenv.2010.01.015

Meyer L, Tsatsaronis G, Buchgeister J, Schebek L (2009) Exergoenvironmental analysis for evaluation of the environmental impact of energy conversion systems. Energy 34:75-89. doi: 10.1016/j.energy.2008.07.018

Mills DR, Bassett IM, Derrick GH (1986) Relative cost-effectiveness of CPC reflector designs suitable for evacuated absorber tube solar collectors. Solar Energy 36:199-206. doi: 10.1016/0038-092X(86)90135-0

Mishra RK, Garg V, Tiwari GN (2017) Energy matrices of U-shaped evacuated tubular collector (ETC) integrated with compound parabolic concentrator (CPC). Solar Energy 153:531-539. doi: 10.1016/j.solener.2017.06.004

Mishra RK, Garg V, Tiwari GN (2015) Thermal modeling and development of characteristic equations of evacuated tubular collector (ETC). Solar Energy 116:165-176. doi: 10.1016/j.solener.2015.04.003 
Moran MJ, Shapiro HN (1993) Fundamentals of Engineering Thermodynamics, Second Edition. doi: $10.1080 / 03043799308928176$

Pei G, Li G, Zhou X, et al (2012) Comparative experimental analysis of the thermal performance of evacuated tube solar water heater systems with and without a mini-compound parabolic concentrating $(\mathrm{CPC}) \operatorname{reflector}(\mathrm{C}<1)$. Energies 5:911-924. doi: 10.3390/en5040911

Petela R (2003) Exergy of undiluted thermal radiation. Solar Energy 74:469-488. doi: 10.1016/S0038092X(03)00226-3

Petela R (2005) Exergy analysis of the solar cylindrical-parabolic cooker. Solar Energy 79:221-233. doi: 10.1016/j.solener.2004.12.001

Rezaie B, Reddy B V., Rosen MA (2015) Exergy analysis of thermal energy storage in a district energy application. Renewable Energy 74:848-854. doi: 10.1016/j.renene.2014.09.014

Rosen MA, Dincer I (1997) Sectoral energy and exergy modeling of Turkey. Journal of Energy Resource Technology Transactions of ASME 119:200-204. doi: 10.1115/1.2794990

Rosen MA, Dincer I (2003) Exergoeconomic analysis of power plants operating on various fuels. Applied Thermal Engineering 23:643-658. doi: 10.1016/S1359-4311(02)00244-2

Saidur R, Ahamed JU, Masjuki HH (2010) Energy, exergy and economic analysis of industrial boilers. Energy Policy 38:2188-2197. doi: 10.1016/j.enpol.2009.11.087

Shekarchian M, Zarifi F, Moghavvemi M, et al (2013) Energy, exergy, environmental and economic analysis of industrial fired heaters based on heat recovery and preheating techniques. Energy Conversion and Management 71:51-61 doi: 10.1016/j.enconman.2013.03.008

Sokhansefat T, Kasaeian A, Rahmani K, et al (2018) Thermoeconomic and environmental analysis of solar flat plate and evacuated tube collectors in cold climatic conditions. Renewable Energy 115:501-508. doi: 10.1016/j.renene.2017.08.057

Tsatsaronis G, Morosuk T (2012) Understanding and improving energy conversion systems with the aid of exergybased methods. International Journal of Exergy 11:518-542. doi: 10.1504/IJEX.2012.050261 